\title{
Monotonicity in word formation: The case of Italo- Romance result state adjectives
}

DOI:

10.1111/1467-968X.12120

\section{Document Version}

Accepted author manuscript

Link to publication record in Manchester Research Explorer

\section{Citation for published version (APA):}

Bentley, D. (2018). Monotonicity in word formation: The case of Italo-Romance result state adjectives.

Transactions of the Philological Society, 116(3), 285-319. https://doi.org/10.1111/1467-968X.12120

\section{Published in:}

Transactions of the Philological Society

\section{Citing this paper}

Please note that where the full-text provided on Manchester Research Explorer is the Author Accepted Manuscript or Proof version this may differ from the final Published version. If citing, it is advised that you check and use the publisher's definitive version.

\section{General rights}

Copyright and moral rights for the publications made accessible in the Research Explorer are retained by the authors and/or other copyright owners and it is a condition of accessing publications that users recognise and abide by the legal requirements associated with these rights.

\section{Takedown policy}

If you believe that this document breaches copyright please refer to the University of Manchester's Takedown Procedures [http://man.ac.uk/04Y6Bo] or contact uml.scholarlycommunications@manchester.ac.uk providing relevant details, so we can investigate your claim.

\section{OPEN ACCESS}




\section{MONOTONICITY IN WORD FORMATION: \\ THE CASE OF ITALO-ROMANCE RESULT STATE ADJECTIVES}

\section{INTRODUCTION}

Although theories of lexical semantic representation generally build up the meaning of predicators incrementally, combining and enriching basic event templates to yield complex event templates, there is currently no agreement on whether word meaning is constructed monotonically, in a way that precludes the elimination of nonidiosyncratic components of meaning. Building upon Rappaport Hovav \& Levin (1998) (see also Kiparsky 1982), Koontz-Garboden (2005, 2007, 2009, 2010, 2012) defended a principle of monotonic composition in a series of contributions on the semantic processes that underlie word formation operations. Koontz-Garboden's claim is that there are no productive word formation operations which delete any decompositional operators that are part of word meaning. He calls this idea the MONOTONICITY HYPOTHESIS. RESULT STATES, i.e., states that ensue from a prior event of change of state (Dixon 1982: 50) are an ideal testing ground for this hypothesis, since their lexical semantic structure is predicted by the hypothesis to comprise a representation of the event that gives rise to the state. Thus, the lexical semantic structure of English reddened ought to include a representation of an event of becoming red. Similarly, the structure of broken ought to include an operator representing an event of breaking, and so forth.

Non-monotonic analyses of result states are not hard to come by. To give but one example, Dubinsky \& Simango (1996: 771-772) argue that unlike verbal passives, which suppress the agent argument, making it unavailable for the assignment of the grammatical function subject, statives remove the agent role from the verb's argument list altogether. Thus, in their view, if the lexical conceptual structure of causative phika 'cook' (Chicheŵa, Bantu) includes both a process $\mathrm{P}$ and a state S (cf. 1a), the lexical structure of the result state phikika 'be cooked' includes neither a process nor an agent, but merely a state (cf. 1b).

a. phika $={ }^{'} \operatorname{cook}(\mathrm{v} .)^{\prime}$ (Chicheŵa) $\mathrm{P}[\mathrm{ACT}(\mathrm{y}, \mathrm{x}) \& N O T \operatorname{COOKED}(\mathrm{x})] \mathrm{T}$ (transition) S[COOKED $(\mathrm{x})]$

b. phikika $=$ 'be cooked' (Chichewa)

$\mathrm{S}[\mathrm{COOKED}(\mathrm{x})]$

(Dubinsky \& Simango 1996: 771-772)

In this article we consider result states on evidence from Italo-Romance. ${ }^{1}$ The bulk of the discussion deals with rhizotonic athematic participles (see Italian cotto < Latin COCTU(M) 'cooked'), which may have an arrhizotonic thematic counterpart (see Sicilian cuòttu/cùattu vs. cuciùtu 'cooked'). ${ }^{2}$ The rhizotonic arrhizotonic pairs are

\footnotetext{
${ }^{1}$ Italo-Romance is a family of Romance languages spoken in Italy. These languages are conventionally referred to as dialects in that, exception being made for Italian, they have very little, if any, sociopolitical recognition. We should stress, however, that they are Romance languages in their own right and not varieties of Italian, the official language of Italy (Maiden \& Parry 1997). Thanks are due to two anonymous reviewers, whose comments significantly enhanced the quality of this paper, and to my native speaker informants of Milanese and Mussomelese: Valeria Figini and, respectively, Silvio Cruschina.

2 We have used accent marks in the orthography of the Italian and Sicilian examples in brackets to highlight the contrast between rhizotonic and arrizhotonic forms, that is, forms stressed on the root and
} 
particularly helpful in the discussion of monotonicity because they offer morphologically transparent evidence for the distinction between homoradical passive, or agentive, and non-passive, or non-agentive, result-state adjectives. The passive adjectives have causative and agentive entailments, as shown by their compatibility with a causer in a by-phrase or a manner adverbial (cf. $2 \mathrm{a}$ ), whereas the non-passive ones do not (cf. 2b). In addition, the non-passive adjectives are compatible with expressions negating an event of change of state with an external cause (cf. 2c).

a. Il vaso asciugato dal vento / con cura. the vase.MSG dry.PTCP.MSG by.the wind with care ${ }^{3}$ 'The vase dried by the wind / with care.'

b. Il vaso asciutto (*dal vento/*con cura). the vase.MSG dry.PTCP.MSG by.the wind with care 'The vase dried/dry (*by the wind / *with care).'

c. Il vaso è asciutto, ma non l' ha asciugato the vase.MSG be.3SG dry.PTCP.MSG but NEG it have.3SG dry.PTCP niente o nessuno. nothing or no one 'The vase is dry, but nothing or no one dried it.'

If adjectives like asciutto 'dry/dried' (cf. 2b-c) were morphologically basic, i.e., they were not the result of a derivational process, they would not pose a problem for the Monotonicity Hypothesis, since the latter is about the treatment of meaning in derivational operations, not about the meaning of underived lexemes. On the other hand, if the non-passive adjectives are not morphologically basic, i.e., they are the output of a synchronic derivational process, the findings in (2c) are problematic, in that the derivation would seem to involve the deletion of operators of cause and change from the meaning of the base.

In the analysis we focus on the rhizotonic non-passive participles, since these are the subclass that challenges the Monotonicity Hypothesis. Unless otherwise stated, we rely on first-hand evidence from Standard Italian and two dialects (see note 1), which appear to have a large number of rhizotonic arrhizotonic pairs: a GalloItalian dialect of the North of Italy, the variety of Milanese spoken in the area of Milan called Àffori, and a dialect of the extreme South, the variety of Sicilian spoken in Mussomeli. ${ }^{4}$ In agreement with the literature on Italian adjectival participles (Scalise 1995, Thornton 2004, Schwarze 2017, among others), we argue that the nonpassive forms are indeed morphologically derived. The literature mainly discusses adjectives that are homophonous with perfect and passive participles (for example, Italian aperto 'open(ed)'), proposing conversion or, alternatively, the affixation of a zero suffix to the participle as the relevant morphological operations. We focus on the

on the thematic vowel, respectively. In the remainder of this article, we will follow the relevant orthographic conventions and hence we will not indicate graphically the stress on the root or the thematic vowel of Italian and Sicilian participles.

${ }^{3}$ We use the Leipzig abbreviations (see https://www.eva.mpg.de/lingua/resources/glossing-rules.php), with the following additions: $\mathrm{SCL}=$ subject clitic and SUPERL $=$ superlative. The reader should note that we gloss as PTCP the forms which are usually referred to as past participles and as PRSPTCP the form that Italian grammarians usually call gerund. In addition, in the case of the long examples of section 2 , we use these abbreviations sparingly, when glossing is irrelevant to the point being made in the text.

${ }^{4}$ Additional evidence from the variety spoken in the province of Palermo, which the author has native competence of, is referred to as Sicilian. 
rhizotonic adjectives of the rhizotonic $\sim$ arrhizotonic pairs, and, developing an idea by Bentley \& Ledgeway $(2014,1015)$, we argue that they are formed by the addition of a participial allomorph $-T-(-t-,-s-$, and, by hypothesis, $-\varnothing-)$ to a root.

With respect to the semantic process that underlies the derivation of the nonpassive adjectives, we point out that a contradiction test which is often said to diagnose the deletion of a causer (cf. 2c) actually diagnoses the absence, but not the suppression or deletion of a causer. Therefore, our contention is that the non-agentive forms are simply non-causative, rather than decausative. Despite the absence of a causer in their semantics, these forms can have event entailments, which, we argue, can be entailments of the root itself. We thus capitalize on the distinction between change and causation in lexical semantic structure, which was present, though not fully exploited, in Dowty (1979), and was subsequently defended in the semantic decomposition system of Van Valin and LaPolla (1997) (see also Van Valin 2005). We also briefly consider other classes of result states, which are patently not causative and prove to require a monotonic analysis. Therefore, all our findings strongly suggest that result states are unproblematic vis-à-vis the Monotonicity Hypothesis. We propose a monotonic analysis of the semantic process underlying the formation of result-state adjectives, which captures those that are homoradical with causative verbs and the other classes alike.

The article is structured as follows. In section 2, we discuss the Monotonicity Hypothesis, using supporting evidence from Italian adjectival vs. deadjectival pairs, and we begin to introduce the conventions that will subsequently be adopted in the lexical semantic representation of predicates. In section 3, we introduce the rhizotonic arrhizotonic pairs. We then discuss the distinction between passive and non-passive result state adjectives and we claim that this distinction is transparently encoded in the rhizotonic arrhizotonic pairs of the languages under examination ( $\$ 4)$. In section 5, we argue that the rhizotonic non-passive participles are not morphologically basic, but rather derived by the addition of a participial allomorph to a root. We then test the meaning of the non-passive participles in more depth and we argue that their lexical semantic structure includes an operator of change, but no operator of cause (\$6). In section 7, we develop our monotonic account of result state adjectives. We then adduce evidence from other classes of non-passive result-state participles, which lend support to the monotonicity principle $(\S 8)$. Finally, we draw our conclusions in section 9.

\section{The Monotonicity Hypothesis: Property CONCEPT VS. CHANGE OF STATE PAIRS}

Drawing upon Dixon's (1982: 50) seminal work on the distinction between two kinds of state, called property concepts and result states, Koontz-Garboden (2005) observes that the former type of state, which is conceptually basic, tends to be expressed by morphologically basic forms. These forms, in turn, can constitute the base of derivational operations yielding derived forms describing a change of state. Examples from English and Italian are given in (3a-b) (for English see Levin 1993: 245).

(3) a. white $>$ whiten

b. bianco 'white' > imbiancare '(cause to) become white' (Italian)

The morphologically underived form white (compare Italian bianco) is an adjective of colour. This adjective provides the base of a derivational operation, which yields the verb whiten (compare Italian imbiancare), describing a change into 
that colour. There are many such pairs of underived stative adjectives and derived change of state verbs in Italian. The adjectival members of these pairs belong to the categories listed by Dixon (1982) as types of state that do not entail a prior event: colour, size, age, speed, etc. The verbal members of the pairs exhibit an inchoative prefix and verbal morphology: specifically, the thematic vowel that identifies the verbal conjugation (e.g., $-a$ - in imbiancare in $3 b$ ) and, in the infinitive, which is the citation form in Italian, the -re suffix.

(4) Colour

a. giallo 'yellow' > ingiallire '(cause to) become yellow'

(Italian)

b. nero 'black' > annerire '(cause to) become black'

c. rosso 'red' > arrossare '(cause to) become red', arrossire 'blush'

d. verde 'green' > (r)inverdire '(cause to) become green (again)'

(5) $\underline{\text { Size }}$

a. grasso 'fat' > ingrassare '(cause to) become fat'

(Italian)

b. grande 'large' > ingrandire 'enlarge, (cause to) become bigger'

c. piccolo 'small' > rimpicciolire '(cause to) become smaller'

(6) Age

(Italian)

a. giovane 'young' > ringiovanire '(cause to) become young(er looking)'

b. vecchio 'old' > invecchiare '(cause to) become old(er looking)'

(7) Speed

lento 'slow' > rallentare '(cause to) become slower'

(Italian)

That the adjectives in (3b) to (7) are not only morphologically, but also semantically, underived is indicated by the results of tests of compatibility with expressions implying that there is no prior event of change of state (cf. 8a-d) or negating such an event (cf. 9a-d). The outputs of these tests are both semantically coherent and grammatical, which suggests that the adjectives in question do not entail a prior event of change into the state that they describe.

(8) a. Questo prato mi pare verdee mi è sempre parso tale. this meadow me seems green and me is always seemed such 'This field seems green to me and it always seemed like this to me.'

b. Questa immagine mi pare piccola e mi è sempre parsa tale. this image me seems small and me is always seemed such 'This image seems small to me and it always seemed like this to me.'

c. Questo tuo amico mi pare vecchio e mi è sempre parso tale. this your friend me seems old and me is always seemed such 'This friend of yours seems old to me and he always seemed like this to me.'

d. Questo ingranaggio $\mathrm{mi}$ pare lento e mi è sempre parso tale. this gear me seems slow and me is always seemed such 'This gear seems slow to me and it always seemed like this to me.'

(Italian)

(9) a. Questo prato è verde, ma non è diventato (più) verde. this meadow is green but NEG is become more green 'This field is green, but it has not become green(er).'

b. Questa immagine è piccola, ma non è diventata (più) piccola. 
this image is small but NEG is become more small

'This image is small, but it has not become small(er).'

c. Questotuo amico è vecchio, ma non è diventato più vecchio. this your friend is old but NEG is become more old 'This friend of yours is old, but he has not become old(er) (looking).'

d. Questo ingranaggio è lento, ma non è diventato più lento. this gear is slow but NEG is become more slow 'This gear is slow, but it has not become slow(er).'

To be sure, some of the adjectives listed above could, at least in principle, denote states deriving from previous events of change of state: vecchio 'old' would seem to be a prime example of this, as suggested by world knowledge. What matters here is that the underived adjectives do have property concept meanings, which contrast with the meaning of the corresponding deadjectival verbs (cf. $3 \mathrm{~b}$ to 7 ). ${ }^{5}$ The said verbs prove to be semantically, as well as morphologically, derived. Indeed, they are incompatible with expressions negating a previous event of change of state, as suggested by the tests below, where the additions in brackets range from odd (cf. 10ad) to contradictory (cf. 11a-d). this meadow is become.greener.PRSPTCP and me is always seemed che stesse rinverdendo). that be.SBJV.3SG become.greener. PRSPTCP

'This field is becoming greener (\#and it always seemed to me to be becoming greener).'

b. Questa immagine sta rimpicciolendo (\# e mi è sempre parso this image is become.smaller.PRSPTCP and me is always seemed che stesse rimpicciolendo).

that be.SBJV.3SG become.smaller. PRSPTCP

'This image is becoming smaller (\#and it always seemed to me to be becoming smaller).'

c. Questo tuo amico sta invecchiando (\# e mi è sempre parso this your friend is become.older. PRSPTCP and me is always seemed che stesse invecchiando).

that be.SBJV.3SG become.older. PRSPTCP

'This friend of yours is becoming old(er) (looking) (\#and he always seemed to me to be becoming old(er) (looking)).'

d. Questo ingranaggio sta rallentando (\# e mi è sempre parso this gear is become.slower.PRSPTCP and me is always seemed che stesse rallentando).

that be.SBJV.3SG become.slower. PRSPTCP

'This gear is becoming slower (\#and it always seemed to me to be becoming slower).'

\footnotetext{
${ }^{5}$ As was pointed out to me by Ricardo Bermúdez Otero, the property concept or result state meaning of morphologically underived adjectives is diagnosed by the alternation of the copulas ser and estar in Spanish. Thus ser rojo means 'to be red by nature', whereas estar rojo means 'to be red as a result of becoming red (for example, in an event of blushing)'. While the fact that morphologically underived forms can have result state meanings is by no means trivial, it is also unproblematic for the theoretical distinction between property concepts and result states and for the derivational operation described above.
} 
(11) a. Quest' anno questo prato è rinverdito,

(Italian)

this year this meadow is become.greener.PTCP

(*ma non è diventato più verde).

but NEG is become.PTCP more green

'This year this field has become greener, (*but it has not become greener).'

b. Questa immagine è rimpicciolita (sullo schermo),

this image is become.smaller.PTCP on.the screen

(*ma non è diventata più piccola).

but NEG is become.PTCP more small

'This image has become smaller (on the screen), (*but it has not become smaller).'

c. Questo tuo amico è invecchiato (velocemente),

this your friend is become.older.PTCP quickly

(*ma non è diventato più vecchio).'

but NEG is become.PTCP more old

'This friend of yours has (quickly) become old(er) (looking), (*but he has not become old(er) (looking).'

d. Questo ingranaggio è rallentato (ogni giorno di più),

this gear is become.slower.PTCP every day of more

(*ma non è diventato più lento).

but NEG is become.PTCP more slow

'This gear has become slower (every day), (*but it has not become slower).'

Many of the deadjectival verbs in question allow a causative reading, as suggested by the fact that they have transitive counterparts (cf. 12a-d) which can be paraphrased with a syntactic causative (cf. 13a-d).

(12) a. Questo prato, l' hanno rinverdito le pioggie primaverili.

(Italian)

this meadow it have make.greener.PTCP the rains of.the.spring

This field, the spring rain has made it become greener.'

b. Questa immagine, 1' ha rimpicciolita il tecnico.

this image it has make.smaller.PTCP the technician

'This image, the technician has made it become smaller.'

c. Questo tuo amico, l' ha invecchiato la malattia.

this your friend it has make.older.PTCP the illness

'This friend of yours, the illness has made him become old(er) (looking).'

d. Questo ingranaggio, l' ha rallentato la rugine.

this gear it has make.slower.PTCP the rust

'This gear, the rust has made it become slower.'

(Italian)

(13) a. Le pioggie primaverili hanno fatto sì che questo campo rinverdisse. the rains of.the.spring have made so that this meadow become.greener 'The spring rain has made it so that this field would become greener.'

b. Il tecnico ha fatto sì che questa imagine rimpicciolisse. the technician has made so that this image become.smaller 'The technician has made it so that this image would become smaller.'

c. La malattia ha fatto sì che questo tuo amico invecchiasse. the illness has made so that this your friend become.older 
'The illness made it so that this friend of yours would become old(er) (looking).'

d. La rugine ha fatto sì che questo ingranaggio rallentasse. the rust has made so that this gear become.slower 'The rust has made it so that this gear would become slower.'

Contrastingly, a subclass of the deadjectival verbs rejects the causative construal (cf. 14a-b, 15a-b), while entailing an event of change of state (cf. 16a-b, $17 \mathrm{a}-\mathrm{b})$, and hence testing out as semantically derived.

(14) a. bianco 'white' > sbiancare 'become pale" (Italian)

b. rosso 'red' > arrossire 'become red, blush'

(15) a. *Giorgio, lo hanno sbiancato le notizie. (Italian)

George him have made.pale.PTCP the news

'George, the news made him become pale.' [intended reading]

b. *Giorgio, lo hanno arrossito i pettegolezzi.

George him have become.red.PTCP the gossip

'George, the gossip made him blush.' [intended reading]

(Italian)

(16) a. Giorgio sta sbiancando (\# e mi è sempre parso che

George is become.pale.PRSPTCP and me is always seemed that

lo facesse).

it did

George is becoming pale (\#and he always seemed to me to be doing so).'

b. Giorgio sta arrossendo (\# e mi è sempre parso che

George is become.red.PRSPTCPand me is always seemed that

lo facesse).

it did

George is blushing (\#and he always seemed to me to be doing so).'

(17) a. Giorgio è sbiancato al sentire le notizie,

George is become.pale.PTCP at.the hear the news

(*ma non è diventato pallido).

but NEG is become.PTCP pale

'George became pale on hearing the news, (*but he did not become pale).'

b. Giorgio è arrossito al sentire i pettegolezzi,

George is become.red.PTCP at.the hear the gossip

(*ma non è diventato rosso).

but NEG is become.PTCP red

'George blushed on hearing the gossip, (*but he did not blush).'

By contrast with the property concept adjectives listed in (3b) to (7) (cf. 8a-d, $9 \mathrm{a}-\mathrm{d})$, the related deadjectival verbs are thus not only morphologically, but also semantically, complex. Some only entail non-causative change of state events as part

${ }^{6}$ Sbiancare can be causative when its theme argument is inanimate. As expected, in this case it is compatible with an overt causer.

(i) Il bucato, l' ho sbiancato io usando questo prodotto. (Italian) the washing it have.1SG whiten.PTCP I using this product

'The washing, I made it become white using this product.' 
of their meaning (cf. 14a-b to 17a-b), while others can also entail events of change of state that are externally caused (cf. 10a-d to 13a-d). In Levin \& Rappaport Hovav's (1995: 92) terms, externally caused verbs are verbs that 'imply the existence of an "external cause" with immediate control over bringing about the eventuality described by the verb'. The distinction between change and causation in lexical semantic structure (Dowty 1979, Van Valin and LaPolla 1997, Van Valin 2005) will prove to be of fundamental importance in the analysis of result states.

Taking rosso 'red' and arrossire 'become red, blush', on the one hand, and, on the other hand, verde 'green' and rinverdire 'make green(er)' as examples of pairs of state vs. non-causative and, respectively, causative change of state, we tentatively represent the semantic structure of these pairs as in (18)-(19).

(18) a. $\operatorname{red}(x)$

b. BECOME red(x)

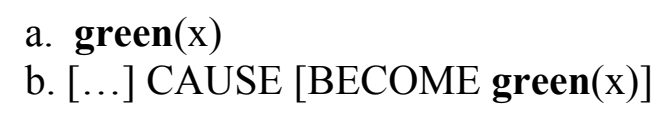

The structures in (18a) and (19a) represent semantically underived state predicates with a single actant argument $\mathrm{x}$. Contrastingly, (18b) represents a change into the state in (18a), exhibiting the operator of change BECOME. Lastly, (19b) represents an externally caused change into the state in (19a). In addition to the change operator, in (19b), there is also an operator of cause (CAUSE). This is preceded by closed brackets, which indicate the causing event with an external cause. More articulated lexical semantic structures will be introduced in due course.

\section{RHIZOTONIC VS. ARRHIZOTONIC PARTICIPIAL PAIRS}

We now turn to the participles that are stressed on the root and lack a thematic vowel (e.g., Italian rotto 'broken', cf. rompere 'break (v.)'; chiuso 'closed', cf. chiudere 'close (v.)'). Romance rhizotonic athematic participles derive from Latin rhizotonic athematic participial forms ending in -SUS (e.g., ACCENSU(M) 'lit') or -TUS (e.g., IUNCTU(M) 'joined') or from Latin adjectives (e.g., SICCU(M) 'dry'). Some such participles were also formed by analogy with the rhizotonic participles of Latin (Laurent 1999; Maiden 1995: 124-127; Rohlfs 1968: 375-377). In terms of their lexical category, some Italo-Romance rhizotonic participles test out both as adjectives and as verbal participles, whereas others solely test out as adjectives. Observe the examples in (20a-b) and (21a-b). While in (20a) Italian rotto 'broken' is the participle of the perfect of a dyadic verb, in (20b) it is a predicative complement following the raising verb 'seem', which suggests that it is an adjective. By contrast, the Mussomelese Sicilian form appisu 'hung' is purely adjectival (cf. 21b), its verbal counterpart appinnutu being thematic and arrhizotonic, i.e., a participle stressed on the thematic vowel (cf. 21a). ${ }^{7}$

\footnotetext{
7 The respective distribution of the members of the rhizotonic arrhizotonic pairs in ascriptive/attributive, passive and perfect constructions varies in the Romance languages, as pointed out by Loporcaro, Pescia \& Ramos (2004) with European Portuguese evidence. To our knowledge, the claims made in this paper are not affected by the said variation. We are interested in splits like the Sicilian one in (21a-b) because such splits help us to identify non-passive result state adjectives, which have been cited in support of non-monotonic analyses of word formation (Meltzer-Asscher 2011, see also Koontz-Garboden 2012).
} 
(20) a. Il peso ha rotto la sedia. (Italian)

the weight have.3SG break.PTCP the chair

'The weight has broken the chair.'

b. La sedia pare rotta.

the chair.FSG seem.3SG break.PTCP.FSG

'The chair seems broken.'

(21) a. Stu quatru ancora un l' a' appinnutu. (Mussomelese)

this picture yet NEG it have.2SG hang.PTCP

'This picture, you have not hung it, yet.'

b. Stu quatru mi pari appisu.

this picture me seem.3SG hang.PTCP.MSG

'This picture seems to me to be hung.'

That the rhizotonic forms can be adjectives is also indicated by number and gender inflection (cf. 20b, 21b), the fact that they are distributed attributively and predicatively (cf. 22a-b to 24a-b), they can be coordinated with adjectives and negated independently (cf. 25a-b to 27a-b), they take comparative and superlative inflection (cf. 28a-b to 30a-b), and they can be predicative complements after 'remain' (cf. 31a-c). These are coding and behavioural properties of adjectives in the languages under scrutiny. ${ }^{8}$ It should be noted that some dialects do not have a morphological superlative in -issim-, but rather form this type of superlative periphrastically (cf. 29b, 30b).
a. Spegni
quella fiamma
accesa.
extinguish.IMP that flame.FSG light.PTCP.FSG
'Extinguish that lit flame.'

(Italian)

b. La fiamma era / sembrava accesa.

The flame.FSG be.PST.3SG seem.PST.3SG light.PTCP.FSG

'The flame was / seemed lit.'

(23) a. Sposta ddru vasu ruttu.

move.IMP that vase.MSG break.PTCP.MSG

'Move that broken vase.'

b. U vasu jèra / pariva ruttu.

the vase.MSG be.PST.3SG seem.PST.3SG break.PTCP.MSG

'The vase was / seemed broken.'

$\begin{array}{lllll}\text { a. Smorsa } & \text { quela } & \text { lus } & \text { pisa. } & \text { (Milanese) } \\ \text { switch.off.IMP } & \text { that } & \text { light.FSG } & \text { light.PTCP.FSG } & \end{array}$

\footnotetext{
${ }^{8}$ As pointed out by Schwarze (2017), and, with respect to the rimanere test, Telve (2016), some of these coding and behavioural properties do not pertain exclusively to adjectives (see Bosque 2014: 5354 for similar considerations on Spanish). With respect to gender and number inflection, we should point out that although this is found on Italian verbal participles, under specific conditions which we will not discuss here, this agreement morphology on verbal participles is severely constrained in Milanese and absent in Sicilian, exception being made for passive verbal participles (Loporcaro 1998: 161-170). In addition, we note that the whole set of coding and behavioral properties listed above is only found on adjectives, which indicates that the forms dealt with here are adjectival. Pescia (2015: 82) also lists another adjectivehood test, namely, the modification with the intensifier bello (lit. 'beautiful', in Italian), which also suggests that these forms are adjectives.
} 
'Switch off that turned-on light.'
b. La
La fiama l' era / la pareva pisa.

The flame.FSG SCL be.PST.3SG SCL seemed PST.3SG light.PTCP.FSG

'The flame was / seemed lit.'

(25) a. Il bucato sembra asciutto e bianco. (Italian)

the washing.MSG seem.3SG dry.PTCP.MSG and white.MSG

'The washing seems dry/dried and white.'

b. Il bucato sembra asciutto, non bianco.

The washing.MSG seem.3SG dry.PTCP.MSG NEG white.MSG

'The washing seems dry/dried, not white.'

(26) a. I robbi parivanu puliti e scia(v)urusi. ${ }^{9}$

The washing.FPL seem.PST.3PL clean.PTCP.FPL and perfumed.FPL

'The washing seemed clean(ed) and perfumed.'

b. I robbi parivanu puliti, no scia(v)urusi.

The washing.FPL seem.PST.3PL clean.PTCP.FPL NEG perfumed.FPL

'The washing seems clean(ed), not perfumed.'

(27) a. I pagn paren nèt e prufümà.

the washing.PL seem.3PL clean.PTCP and perfumed

(Milanese)

'The washing seemed clean(ed) and perfumed.'

b. I pagn paren nèt, minga prufümà.

The washing.PL seem.3PL clean.PTCP NEG perfumed

'The washing seems clean(ed), not perfumed.'

(28) a. Questa camicia è più asciutta di quella. (Italian)

this shirt.FSGbe.3SG more dry.PTCP.FSG than that

'This shirt is drier than that one.'

b. Questa camicia è asciuttissima.

This shirt.FSG be.3sG dry.SUPERL.FSG

'This shirt is very dry.'

(29) a. Sta cammisa jè cchiù asciutta di chiddra. (Mussomelese)

this shirt.FSG be.3SG more dry.PTCP.FSG than that

'This shirt is drier than that one.'

b. Sta cammisa jè asciutta assà.

This shirt.FSG be.3SG dry.PTCP.FSG much

'This shirt is very dry.'

(30) a. Quela camisa qui l' è pusse sucia de quell'altra.

That shirt.FSG DEM SCL be.3SG more dry.PTCP.FSG than that other

'This shirt is drier than that one.'

b. Quela camisa qui l' é tantu sucia.

That shirt.FSG DEM SCL be.3SG very dry.PTCP.FSG

'This shirt is very dry.'

\footnotetext{
${ }^{9}$ Pulitu means 'pretty' in archaic Sicilian, the adjective for 'clean' being nettu (cf. annittari 'clean (v.)'). However, in contemporary varieties of Sicilian, pulitu also means 'clean', possibly as a result of pressure or borrowing from Italian pulito 'clean'. Incidentally, Sicilian also has arrhizotonic pulizziatu 'cleaned', cf. pulizziari 'clean (v.)'.
} 
(31)
a. Quella camicia è rimasta asciutta. (Italian) that shirt.FSGbe.3SG remain.PTCP.FSG dry.PTCP.FSG
b. Sta cammisa arristà asciutta. this shirt.FSG remain.PST.3SG dry.PTCP.FSG
c. Quela camisa qui l' é restada
(Mussomelese)
that shirt.FSG DEM SCL be.3SG remain.PTCP.FSG dry.PTCP.FSG
'This/that shirt remained dry.'

There is cross-dialectal variation in terms of which rhizotonic participles have developed an arrhizotonic counterpart. In addition, in some cases, the rhizotonic forms have been lost, whereas in others it is the innovative arrhizotonic form that has been lost. Below we list some participial pairs in Italian, Sicilian and Milanese.

(32) Italian

accetto / accettato 'accepted'; asciutto / asciugato 'dry, dried'; colmo / colmato 'full, filled'; desto / destato 'awake, woken'; fisso / fissato 'fixed'; guasto / guastato 'rotten, broken, out of order'; lesso / lessato 'boiled'; logoro / logorato 'worn (out)'; perso / perduto 'lost'; sepolto / seppellito 'buried'; volto / voltato 'turned'; unto / untato 'greasy, ointed, oiled'.

(33) Sicilian

apertu / (g)raputu 'open, opened'; asciuttu / asciucato 'dry, dried'; appisu / appinnutu 'hung'; chiusu / chiurutu, chiujutu 'close, closed'; cunchiusu / cunchiurutu 'concluded'; frittu / frijutu 'fried'; guastu / guastatu 'rotten, broken, out of order'; juntu / junciutu 'joint, joined'; muortu / murutu 'dead, died'; pulitu / pulizziatu 'clean, cleaned'; ruttu / rumputu 'broken'; strittu / strinciutu 'tight, narrowed down, tied'; tisu / tinnutu 'stretched'; tuortu / turciutu 'twisted' (Bentley \& Ledgeway 2015: 78).

(34) Milanese

accés / accenduu 'lit'; còtt / cosuu 'cooked'; corètt / coregiuu 'correct, corrected'; fint / fingiuu 'feigned'; miss / mettuu 'put'; pers / perduu 'lost'; risolt / risolvuu 'resolved'; rott / rompuu 'broken'; sospés / sospenduu 'suspended' (Laurent 1999: 171).

Similar pairs are found in other Italo-Romance dialects (see, among others, Ledgeway 2000: 228-233, Pescia 2011) and in Romance languages that do not belong to the Italo-Romance group (Porroche Ballesteros 1990, Laurent 1999, Creissels 2003, Bosque 2014, among others). In fact, Koontz-Garboden (2012) reports the Catalan evidence in (35a-b), where the rhizotonic athematic participle combines with an expression negating a prior event of change of state with an external cause, but the corresponding arrhizotonic participle is incompatibile with the same expression.
a. Aquesta
branca torta
de l' arbre no l' ha
this branch.FSG bend.PTCP.FSG of the tree NEG it have.3SG
torçada res ni ningú; simplement va créixer així.
bend.PTCP.FSG thing or no one simply AUX grow so
b. *Aquesta branca torçada de l' arbre no l' ha
this branch.FSG bend.PTCP.FSG of the tree NEG it have.3SG

(Catalan) 
torçada res ni ningú; simplement va créixer així.

bend.PTCP.FSG thing or no one simply AUX grow so

'This bent branch of the tree hasn't been bent by anything or anyone; it

simply grew this way.' (Koontz-Garboden 2012: 154, footnote 20)

Assuming that rhizotonic participles like torta 'bent' in (35a) are semantically, as well as morphologically, derived, they appear to be problematic for the Monotonicity Hypothesis. The relevant word-formation process would indeed seem to involve the deletion of the operators of change and cause from a semantic structure like the one introduced in (19b) ([...] CAUSE [BECOME state(x)]). KoontzGarboden suggests that torta 'bent' could be a DERIVED STATIVE, i.e., a morphologically derived form that predicates change in a spatial, rather than a temporal, domain: hence, the grammaticality of (35a), where the structure with torta combines with an expression negating a previous event of change of state in a temporal domain.

Comparable evidence is easily constructed in Italo-Romance (cf. 2c). The examples in (36a-b) to (38a-b) exhibit some of the pairs of adjectival participles introduced above, which are homoradical with change of state verbs: Italian asciugare 'dry (v.)', Milanese sugà 'dry (v.)' and Sicilian chiùiri 'close (v.)'.

(36) a. Le stoviglie paiono asciugate, (*ma non le ha

(Italian)

the dishes.FPLseem.3PL dry.PTCP.FPL but NEG them have.3SG

asciugate niente $\mathrm{o}$ nessuno).

dry.PTCP.FPL nothing or no one

'The dishes seem dried, (*but nothing or no-one dried them).'

b. Le stoviglie paiono asciutte, ma non le ha

the dishes.FPL seem.3PL dry.PTCP.FPL but NEG them have.3SG

asciugate niente o nessuno.

dry.PTCP.FPL nothing or no one

'The dishes seem dry, but nothing or no-one dried them.'

a. U purtuni jè(ni) chiujùtu, (*ma unn'u chiujì nuddru).

The gate.MSG be.3SG close.PTCP.MSG but NEG it close.PST.3SG no one

'The gate is closed, (*but nobody closed it).'

b. U purtuni jè(ni) chiusu, ma unn'u chiujì nuddru.

The gate.MSG be.3SG close.PTCP.MSG but NEG it close.PST.3SG no one

'The gate is close, but nobody closed it.'

(38) a. I pagn pareven sugaa (dal vent), (*ma $i$ aveva

(Milanese)

the washing.PL seem.PST.3PL dry.PTCPby.the wind but them had

sugaa nissun/nient).

dry.PTCP no one nothing

'The washing seemed dried (by the wind), (*but nothing or no-one had dried it.)'

b. I pagn pareven succ', ma i aveva sugaa the washing.PL seem.PST.3PL dry.PTCP but them have.PST.3sGdry.PTCP nissun/nient.

no one nothing

'The washing seemed dry, but nothing or no-one had dried it.' 
Observe that the participles under discussion, with the possible exception of (37b), do not describe the result of a change in a spatial domain. Therefore, the issue begs for an explanation that looks beyond derived statives. The rhizotonic forms could of course be morphologically underived. Accordingly, the evidence in (36b), (37b) and (38b) would be irrelevant to the Monotonicity Hypothesis, since this is about the semantic processes that underlie productive word formation operations and not about morphologically underived forms. Alternatively, the strong forms could be decausative adjectives, derived from roots or bases describing a change of state with an external cause (cf. 19b) by a productive word formation process that deletes the CAUSE operator, as well as the causer, from the meaning of the root. In the latter case, one would also have to test whether the CHANGE operator is similarly deleted. The latter process would patently contravene the principle of monotonicity.

\section{PASSIVE AND NON-PASSIVE ADJECTIVAL RESUlT STATES}

As we pointed out in section 1, Dubinsky \& Simango (1996: 771-772) argue that, unlike passives, statives remove the agent role from the verb's argument list (cf. 1ab). Another non-monotonic account is Meltzer-Asscher's (2011) analysis of Hebrew result state adjectives. Like the Romance adjectives discussed above, these are members of pairs. The two members of these pairs are called by Meltzer-Asscher (2011) 'true' adjectival passives and, respectively, decausatives.

\begin{tabular}{|l|l|l|}
\hline Transitive verb & 'True' adjectival passive & Adjectival decausative \\
\hline hevix 'embarrass' & muvax 'embarassed' & navox 'embarrassed' \\
\hline histir 'hide' & mustar 'hidden' & nistar 'hidden' \\
\hline
\end{tabular}

Table 1. Hebrew cause verbs with two adjectival forms (Meltzer-Asscher 2011: 831)

Adjectival passives are known to license by phrases, purpose clauses, instruments, as well as manner adverbs adding to the description of the state denoted by the adjective (Wasow 1977, Kratzer 1994, 2000, Dubinky \& Simango 1996, Embick 2004, Maienborn 2009, Meltzer-Asscher 2011, Pescia 2015, Anagnostopoulou \& Samioti 2013, among others). ${ }^{10}$ Applying these tests, Meltzer-

\footnotetext{
${ }^{10}$ In fact, only some approaches to adjectival passives take these to allow a by phrase, a case in point being Meltzer-Asscher (2011: 826), who notes that the by phrase licensed by adjectival passives must introduce a participant who is detectable from the state described by the passive. There is not much literature on adjectival passives in Italian. We refer to Thornton (2004: 531-532) and Telve (2016: 35) for some relevant observations. We also note that Schwarze (2017) reports authentic Italian examples of unambiguously adjectival participles taking a by phrase.
}

[...] dal maestro francese, sempre lettissimo

da studiosi $[\ldots]$

by.the master.MSG French always read.PTCP.SUPERL.MSG by scholars

'By the French master, who is always read by many scholars.'

(Schwarze 2017:312)

(ii) $[\ldots]$ ha trovato la porta aperta dai ladri [...] (Italian)

have.3SG find.PTCP the door.FSG open.PTCP.FSG by.the burglars

'S/he found the door opened by burglars.'

(Schwarze 2017:312)

These would seem to be genuine examples of adjectival passive participles in Italian, i.e., participles with morphological and distributional properties of adjectives, which have a demoted agentive argument realized in a $b y$-phrase, as is the case with the demoted agent of verbal passives. In any case, 
Asscher (2011) claims that only one member of the pairs exemplified in Table 1 is a 'true' adjectival passive, while the other one is not. Indeed, these tests suggest that one adjectival form entails an implicit agent or instrument (cf. 39a), while the other adjectival form does not (cf. 39b).

(39) a. ha-bama tihiye mustered be-emca'ut pargod. (Hebrew)

b. *ha-bama tihiye nisteret be-emca'ut pargod.

the-stage will+be hidden by means of screen

'The stage will be hidden with a screen.' (Meltzer-Asscher 2011: 832)

Meltzer-Asscher (2011) proposes a non-monotonic decausative analysis of the adjectives that are not 'true' adjectival passives, capitalizing on the results of the test introduced above in (2c) and (35) to (38).

(Hebrew)

(40) a. \#maks yihiye muvax, lamrot še-haf exad/ šum davar lo yavix oto.

b. maks yihiye navox, lamrot še-haf exad/ šum davar lo yavix oto.

Max will+be embarrassed, though that-no one/nothing not will+embarrass him.

'Max will be embarrassed, though no one / nothing will embarrass him.'

(Meltzer-Asscher 2011: 831)

Some Hebrew causative verbs only have one adjectival counterpart (see Table 2). Meltzer-Asscher (2011) claims that, in this case, the adjectival form is ambiguous between a 'true' adjectival passive and an adjectival decausative reading, as suggested by the fact that, whereas these adjectival forms are compatible with expressions denying that the state was brought about by a causer, as is expected of decausatives, they also pass the tests that detect an implicit agent, as is expected of adjectival passives. Crucially, the two kinds of test cannot be passed at the same time, which suggests that the distinction between an adjectival passive proper and another adjectival form remains valid, although in these cases it is not manifested in the morphology.

\begin{tabular}{|l|l|}
\hline Transitive verb & Adjectival alternate \\
\hline šavar 'break' & šavur 'broken' \\
\hline sagar 'close' & sagur 'closed' \\
\hline patax 'open' & patuax 'open, opened' \\
\hline
\end{tabular}

Table 2. Hebrew cause verbs with only one adjectival alternate (Meltzer-Asscher 2011: 833)

The Italo-Romance participial pairs in which the arrhizotonic form figures not only in the perfect, but also in the passive, provide transparent morphological evidence for the distinction of two types of adjectival participle. The arrhizotonic form is compatible with by-phrases, instruments, purpose clauses, and manner adverbs which, while adding to the description of the resultant state, relate to the agent, effector or instrument of the process that led to that state. Contrastingly, the rhizotonic form rejects these additions. 
(41) a. I piatti parevano asciugati / *asciutti (Italian)

the dish.MPL seem.PST.3PL dry.PTCP.MPL dry.PTCP.MPL

con uno straccio sporco.(Italian)

with a cloth dirty

'The dishes seemed dried with a dirty cloth.'

b. Stu quatru jè(ni) appinnutu/ *appisu (Mussomelese)

this picture.MSG be.3SG hang.PTCP.MSG hang.PTCP.MSG

cu i chiova

with the nails

'This picture is hung with nails.'

c. I pagn pareven sugaa/ *succ' (Milanese)

the washing.PL seem.PST.3PL dry. PTCP dry. PTCP

dal vent.

by.the wind

'The washing seemed dried by the wind.'

d. I pignat in sugaa / *succ' cunt un straš spurc. (Milanese) the dish.PL be.3PL dry.PTCP dry. PTCP with a cloth dirty

'The dishes are dried with a dirty cloth.'

The arrhizotonic member of the pairs is incompatible with an expression denying that the state being described was brought about by an event of change of state with a causer (cf. 42a, 43a, 44a). The rhizotonic one, instead, passes this test (cf. $42 b, 43 b, 44 b)$.

(42) a. Le stoviglie paiono asciugate (con cura), (*ma non le ha

(Italian) the dishes.FPLseem.3PL dry.PTCP.FPL with care but NEG them have.3SG asciugate niente o nessuno).

dry.PTCP.FPL nothing or no one

'The dishes seem dried (with care), (*but nothing or no-one dried them).'

b. Le stoviglie paiono asciutte, ma non le ha

the dishes.FPL seem.3PL dry.PTCP.FPL but NEG them have.3SG

asciugate niente o nessuno.

dry.PTCP.FPL nothing or no one

'The dishes seem dry, but nothing or no-one dried them.'

(43) a. U purtuni jè(ni) chiujutu, (*ma unn'u chiujì nuddru). the gate.MSG be.3SG close.PTCP.MSG but NEG it close.PST.3SG no one 'The gate is closed, (*but nobody closed it).'

b. U purtuni jè(ni) chiusu, ma unn'u chiujì nuddru. the gate.MSG be.3SG close.PTCP.MSG but NEG it close.PST.3SG no one 'The gate is close, but nobody closed it.'

(44)
a. I pagn pareven sugaa (dal vent), the washing.PL seem.PST.3PL dry.PTCP by.the wind (*ma i aveva sugaa nissun/nient). but them have.PST.3SGdry PTCP no one nothing 'The washing seemed dried (by the wind), (*but nothing or no-one had dried it.)' 


\section{b. I pagn pareven succ', ma i aveva. the washing.PL seem.PST.3PL dry.PTCP but them have.PST.3SG sugaa nissun/nient dry.PTCP no one nothing 'The washing seemed dry, but nothing or no-one had dried it.'}

As was mentioned in the previous section, some rhizotonic participles lack an arrhizotonic counterpart, although such cases are rarer in the dialects than in Italian. ${ }^{11}$ These strong participles are compatible with expressions negating a prior event of change of state with an external causer (cf. 45a), while also passing adjectival passive tests (cf. 45b).
a. La sedia
è rotta,
ma non 1' ha
the chair.FSG be.3SG break.PTCP.FSG but NEG it have.3SG
rotta niente o nessuno.
break.PTCP.FSG nothing or no one
'The chair is broken, but nothing or no-one broke it.'
b. La sedia è rotta dal peso / apposta.
the chair.FSG be.3SG break.PTCP.FSG by.the weight deliberately
'The chair is broken by the weight / deliberately.'

As is the case with the Hebrew ambiguous forms (see Table 2), the two types of test cannot be passed at the same time (cf. 46a-b), which suggests that, in these cases, too, a distinction ought to be drawn between an agentive adjectival passive form and a non-agentive adjectival form, although the two happen to be homophonous.
(46)
a. La sedia è rotta (*apposta/ *dal peso), the chair.FSG be.3SG break.PTCP.FSG deliberately by.the weight ma non l' ha rotta niente 0 nessuno.
but NEG it have.3SG break.PTCP.FSG nothing or no one
'The chair is broken $(*$ deliberately/*by the weight), but nothing or no-one broke it.'
b. La sedia è rotta apposta / dal peso, the chair.FSG be.3SG break.PTCP.FSG deliberately by.the weight (*ma non l' ha rotta niente o nessuno). but NEG it have.3SG break.PTCP.FSG nothing or no one
'The chair is broken deliberately/by the weight, (*but nothing or no-one broke it).'

It thus appears that two types of result state adjectives ought to be differentiated in Italo-Romance, as has been proposed for Chichewa (see §1), Hebrew and other languages, and that only one of these types passes the standard adjectival passive tests, which detect an agent argument in the semantics. In the discussion that follows, we will only briefly touch upon the formation of the Italo-Romance agentive adjectival participles, since these participles do not challenge the Monotonicity

\footnotetext{
${ }^{11}$ For Italian, we only need to mention aperto 'open(ed)', appeso 'hung', chiuso 'close(d)', concluso 'concluded', fritto 'fried', giunto 'joint'; morto 'dead, died'; rotto 'broken'; stretto 'narrowed down, tied'; torto 'twisted', etc. As for the dialects, two such participles are rot 'broken' and fritt 'fried' in Milanese. Mussomelese ruttu 'broken' is marginally acceptable in the perfect and the passive, although it also alternates with rumputu.
} 
Hypothesis. Contrastingly, the non-agentive adjectival participles are of interest to us, because of the results of the test in (42b), (43b), (44b), which suggests that they lend themselves to a decausative analysis of the kind proposed by Meltzer-Asscher (2011) for Hebrew.

To assess the challenge posed by the non-passive result state adjectives to the monotonic principle, we will test the meaning of these adjectives further (see §6). Before we do so, however, we must ascertain whether they are morphologically derived, thus being of interest in the context of the analysis of the semantic processes underlying word formation. It is to this issue that we now turn.

\section{THE MORPHOLOGY OF THE NON-PASSIVE RHIZOTONIC PARTICIPLES}

We begin by noting that on a par with the arrhizotonic forms, the rhizotonic ones exhibit a participial allomorph (-t- or $-s-)$, which strongly suggests that they are not morphologically basic.

(47) a. aperto 'open', asciutto 'dry', perso 'lost', rotto 'broken', etc. (Italian)

b. accés 'lit', còtt 'cooked', corètt 'correct', fint 'feigned', etc. (Milanese)

c. apertu 'open', muortu 'dead', tis $\underline{u}$ 'stretched', tuortu 'twisted', etc. (Sicilian)

Traditionally, it has been assumed that Italian adjectival participles derive from their verbal counteparts by conversion or zero affixation (Scalise 1995: 507-508, Thornton 2004, Schwarze 2017). An illustration of this analysis, using the participle of the verb determinare 'determine', is provided here.

(48) a. $[\text { determina }(r e)]_{\mathrm{V}}=>\left[\right.$ determinato $_{\mathrm{V}}=>\left[\right.$ determinato $_{\mathrm{A}}($ Italian $)$

b. $[\text { determinato }]_{\mathrm{V}}=>\left[\left[\text { determinato }_{\mathrm{V}}+\varnothing\right]_{\mathrm{A}}(\right.$ Scalise 1995: 508)

In support of the conversion analysis, Thornton (2004) observes that the same participial allomorph occurs on both verbal and adjectival forms. For example, $-s-$ occurs in verbal and adjectival chiuso 'close(d)', whilst -t- occurs on rotto 'broken'. The conversion analysis is potentially problematic for the Monotonicity Hypothesis, since the morphological derivation of non-agentive non-passive forms from agentive passive ones would involve a semantic deletion operation (the deletion of an agent, effector or causer).

While we acknowledge the strength of the conversion analysis, we also note that it does not capture the rhizotonic arrhizotonic pairs. Sicilian tisu 'stretched (adj.)' cannot derive from tinnutu 'stretched (v.)' by conversion or zero affixation. We start from the observation that verbal and adjectival passives are homophonous. Thus, in the Italo-Romance rhizotonic arrhizotonic participial pairs, it is the member that is homophonous with the verbal participle that consistently tests out as passive and agentive (cf. 36a, 37a, 38a). In this light, we propose that only adjectival passive participles (see note 10) are formed from verbal passive participles by conversion. This is not only the case with the arrhizotonic members of the rhizotonic $\sim$ arrhizotonic participial pairs, but also with the adjectival passives of other verbs. Some examples are provided in (49a-b) and (50a-b), where the (a) sentences exhibit adjectival passives, whilst the $(\mathrm{b})$ ones exhibit verbal passives.
a. Il romanzo più letto dagli italiani. (Italian)
the novel.MSG most read.PTCP.MSG by.the Italians 
'The novel with the largest Italian readership.'
b. Il romanzo è stato letto
the novel.MSG be.3SG be.PTCP.MSG read.PTCP.MSG by.the Italians
'The novel was read by the Italians.'
(50) a. Un professore molto stimato dagli studenti. (Italian)
a lecturer.MSG very esteem.PTCP.MSG by.the students
'A lecturer who is held in high esteem by the students.'
b. Il professore è stato stimato dagli studenti.
the lecturer be.3SG be.PTCP.MSG esteemed.PTCP.MSG by.the students
'The lecturer was held in high esteem by the students.'

That adjectival passive participles are derived from verbal passive participles by conversion is also suggested by the unavailability of adjectival passives for the biargumental verbs that are not transitive and do not passivize. This is the case with dative experiencer verbs in Italian, which are exemplified by piacere 'like, please' below. Examples (51a) and (51b) indicate that this verb is not transitive and, respectively, does not passivize; example (51c) suggests that it has a dative experiencer subject (or quirky subject); lastly, (51d) shows that it does not have an adjectival passive.

(51) a. *I bambini piacciono molto il gelato.

(Italian)

the children like.3PL much the ice cream

'Children like ice cream very much.'

b. *Il gelato è stato piaciuto dai bambini. the ice cream.MSG be.3SG be.PTCP.MSG like.PTCP.MSG by.the children 'The ice cream was liked by the children.'
c. Ai bambini è piaciuto il gelato.
to.the children be.3SG like.PTCP.MSG the ice cream.MSG

'The children liked the ice cream.'
d. *Il gelato molto piaciuto dai bambini.
the ice cream.MSG very like.PTCP.MSG by.the children
'The ice cream that children like a lot.'

Incidentally, conversion is the analysis proposed for English adjectival passives in Levin and Rappaport Hovav's (1986) seminal work. If this proposal is on the right track, the conversion process is in no way challenging for the Monotonicity Hypothesis, since the conversion from verbal to adjectival participles is not underpinned by the deletion of an agent in semantics, as suggested by the compatibility of the adjectival passives with a by-phrase (cf. 49a and 50a). ${ }^{12}$

With respect to the formation of non-passive and non-agentive result-state adjectives we advance a different proposal. Building upon Bentley \& Ledgeway (2014, 2015), we suggest that morphologically derived result-state adjectives are formed independently of verbal participles by suffixation of an allomorph of the participle $(-t-,-s-)$ to a change of state root. ${ }^{13}$

\footnotetext{
${ }^{12}$ In principle, conversion could also be the morphological operation that yields the adjectival resultstate participles which are homophonous with participles of so-called unaccusative intransitives (e.g., arrossito 'red/blushed (as a result of becoming red)'. We return to these participles in section 8 .

${ }^{13}$ The rhizotonic arrhizotonic pairs may exhibit root allomorphy as a result of regular phonetic processes. An example of root allomorphy is provided by the Sicilian pair ruttu vs. rumputu 'broken'.
} 
An anonymous reviewer questions the productivity of the operation in (52), suggesting that the word-formation process which yielded the rhizotonic non-passive adjectives belongs to the past and is no longer productive in synchrony. This is a nontrivial point. We note, however, that the audible participial affix of the rhizotonic forms provides an indication of morphological transparency. In fact, in section 8 , we adduce evidence from substandard or emergent Italian, which suggests that affixation with an allomorph of $-T$ - is available as a derivational operation for the formation of new result state adjectives from thematic bases which need not be verbal. In addition, the rhizotonic participles of the rhizotonic arrhizotonic pairs are not a random group of adjectives. Rather, they form a fairly coherent lexical semantic class describing the result of change of state eventualities which can, potentially, have an external cause (for external causation see §2). The coexistence of the homoradical participial pairs in synchrony suggests that the locus of attachment of $-T$ - distinguishes a derivational operation from an inflectional one. The derivational operation starts from an agentless change-of-state root and has an adjective as its output, whereas the inflectional operation starts from an agentive (causative) change-of-state verbal base and has a verbal participle as its output. ${ }^{14}$ Incidentally, by HOMORADICAL pairs we mean forms which share the same root, intended here both as a morphological object and as a lexical semantic object in an event structure.

Admittedly, there exists a class of rhizotonic adjectives which appear to share their root with the participles of change of state verbs, but lack an audible participial allomorph. This class is said to be shortened or truncated (Pescia 2011: 527), so as to distinguish it from the participles that were rhizotonic in Latin. In (53a-c), we illustrate the class with the adjective sveglio 'awake' (cf. 53a) vis-à-vis the perfect and passive participle svegliato 'woken' (cf. 53b-c).

(53) a. Il bambino è sveglio.

(Italian)

the child.MSG be.3SG awake.MPL

'The child is awake.'

b. Il rumore ha svegliato il bambino.

the noise have.3SG wake.PTCP the child

'The noise has woken the child.'

In the rhizotonic participle, the -PT- nexus of Latin RUPTU(M) regularly undergoes regressive assimilation (see Maiden 1995: 71). The arrhizotonic form, which is a later formation, instead exhibits the -MP- nexus of Sicilian rumpiri (< Latin RŬMPERE), which does not undergo assimilation in Sicilian. Allomorphic modification of a root-final dental characterizes many third conjugation participles (e.g., MORDERE 'bite', MORSU(M) 'bitten') (Maiden 1995: 124-125), and the same variation is found in participial pairs whose rhizotonic form did not directly derive from Latin, but rather was formed by analogy with existing strong participles. An example of this is Italian perso 'lost', the strong participle of perdere 'lose' (Cortelazzo-Zolli 1979, s.v. perso). Finally, The roots of the participial pairs may also exhibit allomorphic differences when they are not cognate, but rather derive diachronically from the participles of different verbs. An example of this is the Italian pair asciutto lasciugato 'dried', where the rhizotonic form derives from Latin EXSŪCTU(M), the participle of EXSŪGERE 'suck', while the arrhizotonic form is the participle of the reflex of Late Latin EXSUCĀRE 'to draw out moisture / water' (Cortelazzo-Zolli 1979, s.v. asciugare, asciutto) (in both cases, the prefix EX- was replaced by $\mathrm{AD}-)$.

${ }^{14}$ The same morphological operation can be derivative, in one case, and inflectional, in another (Stump 1998: 19) and we suggest that this is the case with the affixation of -T-. For a morphomic analysis of the - $T$ - participle, see Maiden (2016) and work cited therein. 

c. Il bambino è stato svegliato dal rumore. the child.MSG be.3SG be.PTCP.MSG wake.PTCP.MSG by.the noise 'The child was woken by the noise.'

Other such rhizotonic forms are salvo 'saved', gonfio 'swollen', secco 'dry', etc. Guasto 'rotten, broken, out of order' and desto 'awake' also belong to this class, assuming that the $[\mathrm{t}]$ segment is part of the root. Importantly, the truncated forms are attested as perfect participles in early Tuscan, which is the immediate ancestor of modern Italian. In addition, the truncated forms still occur in the perfect and the passive of other Italo-Romance dialects (see Ascoli 1876: 451, Rohlfs 1968: 375-377, Maiden 1995: 124, Laurent 1999: 163-164, Pescia 2015, Ledgeway 2016: 221). Furthermore, in the Gallo-Italic dialect of Picerno, Basilicata, some truncated participles occur in the perfect, while their full participial counterparts are adjectival.

(54) a. Giuanna a/è maccià/*macciarə la camiscia. (Picerno, Basilicata) Jean has/is stain.PTCP the shirt

'Jean has stained the shirt.'

b. $\mathrm{Lu}$ maglione jè macciarə / *maccià.

the sweater.MSG be.3SG stain.PTCP.MSG stain.PTCP

'The sweater is stained.' (Pescia 2011: 529)

In modern Italian, however, the truncated forms cannot occur in the perfect or the passive. Accordingly, another anonymous reviewer notes that analyzing, and glossing, the modern Italian truncated adjectives as participles formed by adding a zero participial suffix to a change of state root, one fails to capture the diachronic change occurred from early Tuscan to modern Italian. This change is outlined here taking guastare 'rot, break (v.)' as an example.

(55) Perfect and passive participle of guastare:

guasto (early Tuscan) > guasta-to (modern Italian)

We acknowledge that the truncated forms could be underived adjectives that only share their root with the verbs of change of state. In some cases, these forms have undergone processes of semantic shift; for example, Italian sveglio (cf. 53a) can mean 'alert, clever, intelligent'. It could be argued that a possible endpoint of such diachronic processes of semantic change is that, in synchrony, the adjectives may share a root as a morphological object with the perfect and passive participles, but not a root as a lexical semantic object in an event structure. Assuming that the truncated forms are indeed underived adjectives, they are irrelevant to the Monotonicity Hypothesis because this does not make any predictions on morphologically underived words.

On the other hand, the hypothesis that the truncated forms may share the morphological structure that we have proposed for result-state adjectives (cf. 52), thus including a change of state root and an inaudible participial suffix, must be entertained in this context because, should this hypothesis be on the right track, then the forms under discussion would be relevant to the Monotonicity Hypothesis. In the remainder of this article we will thus keep the truncated forms within the scope of the discussion, and, for consistency, we will gloss as $\varnothing$ the putative inaudible suffix. 


\section{THE MEANING OF THE RHIZOTONIC ATHEMATIC PARTICIPLES}

In the previous section we claimed that the rhizotonic result-state participles are morphologically derived and are thus of interest in the context of the Monotonicity Hypothesis. We shall now proceed to further investigation of their meaning. Recall that the hypothesis predicts that a result state derived from a base that describes a change of state (BECOME pred(x), cf. 18b) includes the relevant operator of change in its meaning. Similarly, a result state derived from a base describing a causative event of change of state ([...] CAUSE [BECOME pred(x)], cf. 19b) is predicted to include both an operator of cause and an operator of change. Accordingly, what we need to ascertain is whether the formation of result-state adjectives involves the deletion of any decompositional component of meaning.

Applying relevant compatibility and contradiction tests, it becomes immediately apparent that the Italo-Romance non-passive result state adjectives entail events of change of state. To begin with, assuming with Embick (2004: 357) that the complement of a verb of creation cannot be a state resulting from a prior event, as this would result in contradiction, the facts in (56)-(58), showing that the non-passive participles scarcely lend themselves to being the complements of verbs of creation, suggest that they indeed describe states resulting from prior events of change of state.

a. L'ascensore è stato costruito grande $/{ }^{*}$ guasto. (Italian) the lift.MSG be.3SG be.PTCP.MSG build.PTCP.MSG big.SG break.Ø.MSG 'The lift has been built big / *broken.'

b. L'ascensore è stato costruito grande /??fisso. the lift.MSG be.3SG be.PTCP.MSG build.PTCP.MSG big.SG fix.Ø.MSG 'The lift has been built big /?fixed.'
A. Cùamu jè cuattu stu pollu? how be.3SG cook.PTCP.MSG this chiken.MSG 'How is this chicken cooked?'
B. U pollu jè cuattu (*frittu). the chicken.MSG be.3SG cook.PTCP.MSG fry.PTCP.MSG 'The chicken is (cooked) fried.'
(Mussomelese)
A. Cume l' è faa el pulaster? how SCL be.3SG do.PTCP this chiken 'How is the chicken made?'
B. El pulaster l' è cott (*fritt). the chicken SCL be.3SG cook.PTCP fry.PTCP 'The chicken is (cooked) fried.'
(Milanese)

Importantly, the result-state adjectives in (56a-b), (57B) and (58B) are not attested as passive participles, and hence the above results cannot be ascribed to ambiguity with an adjectival passive reading. ${ }^{15}$

\footnotetext{
${ }^{15}$ An anonymous reviewer notes that it is not at all easy to determine what a verb of creation is and that, with some putative verbs of creation in Italian, the same test would not yield problematic results (for similar considerations, see Telve 2016). We agree with the reviewer and with the similar points made in the literature. In fact, the participle of a verb of change and result is only banned as the complement of a participle describing creation, if any aspect of the change or the result described by the former is incompatible with the change or the result that are part of the process of creation
} 
In terms of the distinction between REPETITIVE and RESTITUITIVE readings ensuing from modification with 'again' (von Stechov 1996, Koontz-Garboden 2012), the rhizotonic participles only lend themselves to a repetitive reading, thus describing repeated events of change into a result state (cf. 59a-c), while ruling out the reading that describes a return to an original state. ${ }^{16}$ The latter reading is found, alongside the repetitive one, with property concept adjectives (cf. 60a-b).

(59) a. L' ascensore è di nuovo guasto.

(Italian)

the lift.MSG be.3SG again break.Ø.MSG

'The lift is broken again.' [repetitive]

b. U quatru jè arrìari appisu.

the picture.MSG be.3SG again hang.PTCP.FSG

(Mussomelese)

'The picture is hung again.' [repetitive]

c. A porta jè arrìari aperta.

(Mussomelese)

the door.FSG be.3SG again open.PTCP.FSG

'The door is open again.' [repetitive]

(60) a. L' ascensore è di nuovo lento.

the lift.MSG be.3SG again slow.MSG

'The lift is broken again.' [restituitive or repetitive]

b. A porta jè arrìari bianca.

the door.FSG be.3SG again white.FSG

'The door is open again.' [restituitive or repetitive]

(Italian)

To be sure, some of the non-passive forms allow non-resultative readings, which are compatible with restituitive again. In Italian this is the case with sveglio in the sense of 'alert, clever, intelligent' (see §5).

(61) Lo studente è dinuovo sveglio.

the student.MSG be.3SG again alert/wake.Ø.MSG

(Italian)

'The student is alert again [restituitive or repetitive].'

'The student is awake again [repetitive].'

These facts are unproblematic because the non-resultative readings are the outcome of idiosyncratic semantic processes and not of productive synchronic word formation operations.

In Spanish, the ambiguity between the resultative and non-resultative readings of such forms is disambiguated by the alternation of the copulas ser and estar (see note 5).

described by the latter. It is, however, necessary to mention this test because the Italo-Romance findings contrast with Embick's (2004) findings on statives such as English dry and open, as well as with Anagnostopoulou \& Samioti's (2013: 225) results on the Greek participles in -tos, which are illustrated here.

(i) Magirepsa to kotopoulo vras-t-o.

(Greek)

cooked.I the chicken boiled

'I cooked the chicken boiled.' (Anagnostopoulou \& Samioti 2013: 225)

${ }^{16}$ As far as we can tell, this test is not available in Milanese because the same form ancamò means 'again' and 'still'. 
(62) a. Es despierto.

(Spanish)

be. $3 \mathrm{SG}$ alert.MSG

'He is alert [mental disposition/character].'

b. Está despierto.

be.3SG wake.PTCP.MSG

'He is awake [as a result of waking up].'

The copula estar, therefore, provides a diagnostic to identify result states, i.e., states that ensue from change of state processes. Importantly, some Spanish rhizotonic participles are solely compatible with estar and reject ser.

(63) a. Está / *Es roto.

(Spanish)

be.3SG be.3SG break.PTCP.MSG

'It is broken.'

a. Está / *Es absuelto

be.3SG be.3SG absolved.PTCP.MSG

'He is absolved.'

To return to Italo-Romance, clear findings are also obtained with the test shown in (64) to (66), which indicates that the non-passive adjectives are incompatible with an expression negating a prior change of state named by the same root. This result is independent of whether the rhizotonic form is unambiguously non-passive (cf. 66a vs. 66b).

(64) a. L' ascensore è rotto, (*ma non si è rotto). (Italian) the lift.MSG be.3SG break.PTCP.MSG but NEG REFL be.3sG break.PTCP.MSG 'The lift is broken, (*but it did not break).'

b. Il bucato è asciutto, (*ma non si è asciugato). the washing.MSG be.3SG dry. PTCP.MSG but NEG REFL be.3SG dry.PTCP.MSG 'The washing is dry (/dried), (*but it did not dry).'

(65) a. L' ascensori jè ruttu, (*ma un s' a rumputu). the lift.MSG be.3sG break.PTCP.MSG but NEG REFL have.3SG break.PTCP 'The lift is broken, (*but it did not break).'

b. I robbi su(nnu) asciutti, (*ma un s' annu asciucatu). the washing.FPL be.3PL dry.PTCP.PL but NEG REFL have.3PL dry.PTCP 'The washing is dry (/dried), (*but it did not dry).'

(66) a. La porta l' è verta, (*ma la s' è minga the door.FSG SCL be.3SG open.PTCP.FSG but SCL REFL be.3SG NEG dervida). open.PTCP.FSG

'The door is open, (*but it did not open).'

b. I pagn in succ', (*ma s' in minga sugaa). the washing.PL be.3PL dry.PTCP but REFL be.3PL NEG dry.PTCP 'The washing is dry (/dried), (*but it did not dry).'

The same result is shown in (67), where the non-passive adjectives fail to combine with a negated clause where the adjective figures as the complement of 'become'. 
a. L' ascensore è rotto, (*ma non è (Italian)

the lift.MSG be.3SG break.PTCP.MSG but NEG be.3SG

diventato rotto).

become. PTCP.MSG break.PTCP.MSG

'The lift is broken, (*but it has not become broken).'

b. Il bucato è asciutto, (*ma non è

the washing.MSG be.3SG dry.PTCP.MSG but NEG be.3SG

diventato asciutto).

become.PTCP.MSG dry.PTCP.MSG

'The washing is dry/dried, (*but it has not dried).'

Again these findings contrast neatly with the results obtained when the same tests are applied to property concept adjectives.

(68) a. L' ascensore è lento, (ma non ha rallentato). (Italian) the lift.MSG be.3SG slow. MSG but NEG have.3SG slow.down.PTCP 'The lift is slow, (*but it has not slowed down).'

b. L' ascensore è lento, (ma non è the lift.MSG be.3SG slow.MSG but NEG be.3SG diventato lento). become.PTCP.MSG slow.MSG

'The lift is slow, (but it has not become slow).'

The truncated forms that lack an audible realization of a participial allomorph yield equally clear results (cf. 69 to 71), unless they allow non-resultative readings (cf. 72), in which case the same compatibility tests give results that some native speakers find acceptable, given a suitable context.

(69) a. Il bambino è sveglio, (*ma non si

(Italian) the child.MSG be.3SG wake.Ø.MSG but NEG REFL è svegliato).

be.3SG wake.PTCP.MSG

'The child is awake, (*but he has not woken up).'

b. Il naufrago è salvo, (*ma non si

the shipwrecked.MSG be.3SG save.Ø.MSG but NEG REFL

è salvato).

be.3SG save.PTCP.MSG

'The shipwrecked is safe/saved, (*but he has not become safe).'

(70) U palluni jè unchiu, (*ma un s' a unchiatu).

the ball.MSG be.3SG inflate.Ø.MSG but NEG REFL have.3SG inflate.PTCP

'The ball is inflated, (*but it has not become inflated).'

(71) a. El fieu l' è svegli, (*ma el s' è

(Milanese)

the child.MSG SCL be.3SG wake.Ø.MSG but SCL REFL be.3SG

minga svegliaa).

NEG wake.PTCP

'The child is awake, (*but he has not woken up).' 
a. El balun l' è gunfi, (*ma el s' è the ball.MSG SCL be.3SG inflate.Ø.MSG but SCL REFL be.3SG minga gunfiaa).

NEG inflate.PTCP

'The ball is inflated, (*but it has not become inflated).'

(72)
a. Marco è (un ragazzo) sveglio, (?ma non si Mark be.3SG a boy.MSG clever but NEG REFL
è svegliato: lo è sempre stato).
be.3SG wake.PTCP.MSG it be.3SG always be.PTCP.MSG
'Mark is (a) clever (boy), (but he has not become clever: he was ever thus).'

As was mentioned in passing, the non-resultative readings of these adjectives are irrelevant to our present purposes, because they are not acquired by a synchronic morpho-semantic operation, but rather by idiosyncratic processes of semantic shift. Similar processes have occurred with the rhizotonic participles. To give but one example, Sicilian tisu does not only mean 'stretched', but can also mean 'proud', 'self-assured', 'self-confident'. We assume that such processes can ultimately result in polysemy, although this issue is entirely beyond the scope of this article. In light of the evidence in (56) to (71), we conclude that the Italo-Romance non-passive resultstate adjectives entail change of state events, and, in this sense, are unproblematic for the Monotonicity Hypothesis. Observe that our findings are in agreement with Meltzer-Asscher's (2011) results on Hebrew (see Tables 1 and 2).

The next step in the analysis of the meaning of the rhizotonic result state participles is to test the evidence for the deletion of a causer. Recall the compatibility test introduced in (36b), (37b) and (38b), which has been cited by others in support of the deletion analyses.

(73) a. Le stoviglie sono asciutte, ma non le ha
the dishes.FPL be.3PL
dry.PTCP.FPL but NEG them have.3sG

asciugate niente o nessuno.

dry.PTCP.FPL nothing or no one

'The dishes seem dry (/dried), but nothing or no one dried them.'

b. U purtuni jè(ni) chiusu, ma unn'u chiujì nuddru.

(Mussomelese) the gate.MSG be.3SG close.PTCP.MSG but NEG it close.PST.3SG no one

'The gate is closed, but no one closed it.'

c. I pagn pareven succ', ma i aveva.

the washing.PL seem.PST.3PL dry.PTCP but them have.PST.3SG

sugaa nissun/nient

dry.PTCP no one nothing

'The washing seemed dry (/dried), but nothing or no one had dried it.'

We claim that the findings in (73a-c) are not indicative of causer deletion because exactly the same results are obtained when the test is applied to property concept adjectives.
a. Le pareti
paiono bianche,
ma non le ha the wall.FPL seem.3PL white.FPL

(Italian)

(Milanese) 
imbiancate niente o nessuno.

whiten.PTCP.FPL nothing or no one

'The walls seem white, but nothing or no one whitened them.'

b. La gonna è corta, ma non l' ha accorciata

the shirt.FSG be.3SG short.FSG but NEG it have.3SG shorten.PTCP.FSG

niente o nessuno.

nothing or no one

'The shirt is short, but no one or nothing shortened it.'

(Mussomelese)

c. I mura jèranu bianchi, ma un l' aviva

the wall.PL be.PST.3PL white.PL but NEG them have.PST.3SG

allattatu nuddru.

whiten.PTCP no one

'The walls were white, but no one had whitened them.'

d. A gonna jè curta, ma un l' a accurzatu

the shirt.FSG be.3SG short.FSG but NEG it have.3SG shorten.PTCP

nuddru.

no one

'The shirt is short, but no one shortened it.'

e. I mur pareven bianc, ma i aveva

(Milanese)

the walls seem.PST.3PL white but them have.PST.3SG

sbiancaa nissun/nient.

whiten.PTCP no one nothing

'The walls seemed white, but nothing or no one had whitened them.'

f. La sutana 1 ' è curta, ma l' ha scurtada nessun

the shirt.FSG SCL be.3SG short.FSG but it have.3SG shorten.PTCP.FSG no one

'The shirt is short, but no one shortened it.'

The adjectives 'white' and 'short' describe property concepts and, indeed, are part of alternations of the kind discussed in section 2. Therefore, the fact that ascriptive constructions with these adjectives can be combined with the addition 'but no one did it' (cf. 74a-f) must mean that this combination does not diagnose causer deletion, but rather the mere absence of a CAUSE operator, and a causer, in lexical semantic structure. We have ascertained that the rhizotonic adjectives that are our main focus are not property concepts, in that they have a change of state as part of their meaning (cf. 56-71). Accordingly, what the comparison of (73a-c) and (74a-f) suggests is that the rhizotonic forms are simply non-causative, rather than decausative.

The lack of the morpheme SE in copular constructions where these adjectives are subject predicative complements also suggests that they are non-causative, as opposed to decausative. Indeed, the absence of SE in such constructions contrasts with its obligatoriness in clauses with homoradical anticausative verbs. Relevant evidence was provided in (64)-(66) and is repeated here for ease of exposition.

(75) a. L' ascensore è rotto, (*ma non si è (Italian)

the lift.MSG be.3SG break.PTCP.MSG but NEG REFL be.3SG

rotto).

break.PTCP.MSG

'The lift is broken, (*but it did not break).' 
b. I robbi su(nnu) asciutti, (*ma un $\underline{s}$ annu $\begin{gathered}\text { (Mussomelese) } \\ \text { asciucatu). }\end{gathered}$ the washing.PL be.3PL dry.PTCP.PL but NEG REFL have.3PL dry.PTCP 'The washing is dry (/dried), (*but it did not dry).'

c. La porta l' è verta, (*ma la $\underline{s}^{\prime}$ è

(Milanese)

the door.FSG SCL be.3SG open.PTCP.FSG but SCL REFL be.3SG

minga dervida).

NEG open.PTCP.FSG

'The door is open, (*but it did not open).'

d. I pagn in succ', (*ma $\underline{s}^{\prime}$ in minga sugaa). the washing.MPL be.3PL dry.PTCP but REFL be.3PL NEG dry.PTCP 'The washing is dry (/dried), (*but it did not dry).'

The morpheme SE figures on the inchoative members of Romance inchoativecausative pairs, signalling the suppression of an external causer (Labelle 1992, based on Rothemberg 1974, Cennamo 1993, 1999, Bentley 2006, 2016; for external causation see section 2). While being relevant to the issue of monotonicity, in-depth discussion of how one should characterise the suppression of the causer in the lexical semantic structure of inchoatives would be beyond the scope of this article. What should be noted here is that the result state adjectives do not exhibit SE. Instead, this morpheme figures on the homoradical verbs, in the absence of a causer, thus suggesting that only the latter type of structure involves causer suppression. ${ }^{17}$

We thus conclude that the non-passive result state adjectives entail events of change of state which are simply non-causative.

\section{A MONOTONIC ACCOUNT OF THE RHIZOTONIC NON-PASSIVE ADJECTIVES}

We can now propose an account of the formation of the rhizotonic non-passive result state adjectives. Returning to the participial allomorph - $--_{-}(-t-,-s-$, and, by hypothesis, $-\varnothing-)$ which was introduced in section 5, we claim that this affix STATIVIZES a base. By this we mean that the addition of the affix changes a change of state base into a result state predicate. In the case of the rhizotonic forms, we propose that this affix attaches directly to a root, turning it into a result state adjective. The idea that the morphological process by which result states are formed involves stativization is widespread in the relevant literature (Dubinsky \& Simango 1996, Meltzer-Asscher 2011, Anagnostopolou \& Samioti 2013, among others). Our proposal differs from the existing ones insofar as the starting point of the operation is concerned. In particular, in the light of the evidence of the rhizotonic participles of the rhizotonic $\sim$ arrhizotonic pairs, we content that the starting point of the operation is not causative, and hence stativization is not concomitant with decausativization. In addition, we claim that the root to which $-T$ - attaches describes a change of state. Admittedly, the idea that roots can have event entailments runs counter to claims made within the framework of Distributed Morphology (see Anagnostopoulou 2003, Embick 2004,

\footnotetext{
${ }^{17}$ The Romance morpheme SE is also claimed to have an Aktionsart function, distinguishing telic from non-telic verbs. Of course, should this be its only function, then its absence in predicative copular constructions with rhizotonic participles would be irrelevant to the question of whether these constructions involve causer deletion. However, in-depth study of the synchrony and diachrony of SE suggests that it can have both functions, at least in Italo-Romance (Bentley 2006, 2012, Cennamo 2012, 2017, Cennamo et. al. 2015).
} 
Anagnostopoulou \& Samioti 2013, among others). However, we note that this idea is not only fully supported by our findings, but also by those of broader typological surveys (see Beavers et al. 2017).

In a model theoretic account it has been proposed that the formation of result states involves existential binding of the event argument of a change of state (KoontzGarboden 2010, 2012).

(76) a. $\lambda \mathrm{x} \lambda \mathrm{s} \lambda \mathrm{e}[\operatorname{BECOME}(\mathrm{e}, \mathrm{s}) \wedge \operatorname{pred}(\mathrm{s}) \wedge \operatorname{THEME}(\mathrm{s}, \mathrm{x})][$ change of state] b. $\lambda \mathrm{x} \lambda \mathrm{s}$ 耐 $[B C O M E(\mathrm{e}, \mathrm{s}) \wedge \operatorname{pred}(\mathrm{s}) \wedge \operatorname{THEME}(\mathrm{s}, \mathrm{x})][$ result state]

The Monotonicity Hypothesis predicts that (76b) can be derived from (76a), but the reverse operation is banned because it would involve the deletion of the existential operator.

We aim to provide lexical semantic representations for the result state adjectives discussed in this paper. From our investigation, it has emerged that the rhizotonic participles have event entailments, but no cause entailments, which means that they are resultative, but not causative. Therefore, our findings lend support to the view that the operators of change and cause ought to be kept separate in lexical semantic structure. This idea was already present in Dowty (1979) and then became a tenet of the system of lexical semantic representation adopted henceforth (Van Valin \& LaPolla 1997, Van Valin 2005). Since the lexical semantic structure of the roots under discussion must describe an event of change of state, which is not in the scope of an operator of cause, we represent this structure as follows (cf. 18).

(77) $\sqrt{ }$ Root $=$ BECOME pred' $(x)$

The affixation with the participial allomorph turns the change of state root into a state adjective, which, crucially, entails the event of change into this state. Enriching the lexical semantic representations introduced in section 2 with predicators that differentiate between activities and states by means of the generalized predicate class markers be' and do' (Van Valin \& LaPolla 1997: 102-103, Van Valin 2005), we propose the following representation for this type of adjective.

$$
\text { [be' (x, [BECOME pred' (x) \& pred' (x)])] }
$$

Be' $^{\prime}$ is not a copula, but the marker of a state predicate in which the contents of the inner square brackets are predicated of the single actant argument $\mathrm{x}$. The contents of the square brackets in (78) represent a state (pred' (x)) which results from an event of changing into that state (BECOME pred' (x)) (The symbol \& connects consecutive event representations (Van Valin \& LaPolla 1997: 109)).

We pointed out that the Monotonicity Hypothesis predicts that (76b) can be derived from (76a), but the reverse operation is banned. Similarly, we derive the lexical semantic structure in (78) from the one in (77) and we reject any analysis that deletes the operator BECOME in (77) to obtain the stative predicate. The reason for rejecting this type of analysis is that, in agreement with the predictions made by the hypothesis, result states have event entailments as part of their meaning, as was abundantly evidenced in (56) to (71). ${ }^{18}$

\footnotetext{
18 Therefore, our proposal constitutes a small departure from and, hopefully, a contribution to the system of lexical decomposition adopted here (Van Valin and LaPolla 1997, Van Valin 2005), in that
} 
In this section we discuss another two classes of result state adjectives, which, we believe, lend strong support to the Monotonicity Hypothesis. To begin with, we consider adjectival participles which are homophonous with the verbal participles of the non-causative de-adjectival verbs introduced in section 2. These are relevant to our purposes because they show that some result-state participles are not morphologically related to causative verbs. Consider arrossire, which means 'become red', in the sense of 'blush' (cf. 79a), and can only be causativized syntactically (cf. 79b).
a. Luca arrossisce
(*Maria).
(Italian)
Luke become.red.3SG Mary
'Luke blushes (*Mary).'
b. Luca fa arrossire Maria.
Luke make.3sG blush.INF Mary
'Luke makes Mary blush.'

The fact that arrossire 'blush' must be embedded in a fare periphrasis to be causativized indicates that it does not describe an externally caused event. Put differently, it is not the inchoative member of a causative/inchoative pair, as is also suggested by the lack of SE in the intransitive structure in (79a).

That the participle arrossito can be an adjective is indicated by its occurrence in predicative and attributive function in (80a) and (80b), respectively, and its compatibility with the superlative inflection (cf. 80b).
a. Maria sembra
arrossita /
arrossitissima.
Mary.FSG seem.3SG become.red.PTCP.FSG become.red.PTCP.SUPERL.FSG
'Mary seems red / very red.'
b. L' arrossitissima ragazza.
the become.red.PTCP.SUPERL.FSG girl.FSG
'The very red girl.'

In particular, arrossito is a result state adjective, given that it rejects an expression that negates an event of 'becoming red' (cf. 81a) and takes a repetitive reading when modified by 'again' (cf. $81 \mathrm{~b}$ ).
a. Maria è
arrossitissima,
$(*$ ma non è
Mary.FSG be.3SG
become.red.PTCP.SUPERL.FSG but NEG be.3SG
diventata rossa).
become.PTCP.FSG red.FSG
'Mary is very red (as a result of blushing), (*but she has not become red).'
b. Maria è di nuovo arrossitissima [repetitive, not restituitive] Mary.FSG be.3SG again become.red.PTCP.SUPERL.FSG

result states are one of very few lexical-semantic structures that are not formed monotonically in this framework. Indeed, they are simply equated to the sub-component pred' $(x)$ of the lexical semantic structure of telic predicates (BECOME pred' $(\mathrm{x})$ ), this representation crucially involving the removal of the telicity operator and any other relevant operator from the semantic structure of the telic predicate (see, e.g., Van Valin \& LaPolla 1997: 103). 
'Mary is very red again (as a result of blushing).'

The event leading to the result state described by arrossito (cf. 80a-b) can be said to involve internal causation, and thus to be an event whereby 'some property inherent to the argument of the verb is "responsible" for bringing about the eventuality" (Levin \& Rappaport Hovav 1995: 91). Therefore, whatever morphological process underlies the formation of this class of adjectives, the issue of whether arrossito is derived by a semantic operation that involves the deletion of a causer cannot arise. In addition, we note that given that the adjective arrossito describes a state of being red that follows a process of becoming red, this process must be part of its meaning.

The class of arrossito could be formed by conversion (see §5), since it is homophonous with the participle of the verb arrossire 'become red, blush'. In the light of the evidence of the rhizotonic arrhizotonic pairs, however, we shall not pursue the conversion analysis, but rather we will extend to this class the proposal advanced in section 7. Specifically, we suggest that the thematic base arrossi- (cf. $82 \mathrm{~b}$ ), which is itself derived from a root meaning 'red' (cf. 82a and §2), combines with the participial allomorph $-t$ - to yield the result state adjective in $(82 \mathrm{c})$.

(82) a. $\sqrt{ }$ Root $=$ red' $(\mathrm{x})$

b. arrossi- $=\mathrm{BECOME}$ red' $(\mathrm{x})$

c. $\operatorname{arrossito}(\mathrm{A})=.\left[\mathrm{be}^{\prime}\left(\mathrm{x},\left[\mathrm{BECOME}\right.\right.\right.$ red' $\left.\left.\left.^{(\mathrm{x})} \& \operatorname{red}^{\prime}(\mathrm{x})\right]\right)\right]$

Our hypothesis is, therefore, that the same derivational operation (attachment of $-T$ - in the formation of result state adjectives) starts from a root, in the case of the rhizotonic participles, and from a thematic base, in the class discussed here. In both cases, the input of the derivation describes a change of state. However, the root of the rhizotonic participles describes an underived change of state (cf. 77), whereas the thematic base in (82b) describes a change of state that derives from a property concept. A unified analysis of the formation of result state adjectives as an operation whereby a participial allomorph, which is a stativizer, changes an eventive base into a state adjective is stronger than a differentiated analysis of affixation vs. conversion because it captures a wider range of facts, i.e., the rhizotonic result states as well as the class of arrossito, in an economical way.

Another class of result-state participles is particularly noteworthy in the discussion of the Monotonicity Hypothesis because of its thematic structure, whereby the agent argument of a verbal participle appears to be treated as the theme of the homophonous result state participle. This class poses a problem for the assumption that result state participles are predicated of the single argument of a root, but agents are licensed in higher functional structure (Embick 2004, see also Kratzer 1994, 1996). An example of this class is the Sicilian adjective manciatu, lit. 'eaten', which describes an individual who has already eaten and needs not eat again, and the Italian adjectives bevuto 'inebriated (as a result of drinking)' and fumato 'stoned (as a result of smoking hash)'. 19

\footnotetext{
${ }^{19}$ This might seem to be a subclass of those participles that Kratzer (2000) calls resultant state passives, since some admit the 'job done' reading that characterizes this class. Note, however, that this reading is not universally compatible with the participles under discussion (see, for example, It. bevuto 'inebriated, drunk' and fumato 'stoned').
} 
a. Vinniru manciati. (Sicilian) come.PST.3PL eat.PTCP.PL

'When they came, they had already eaten.' (Lit. 'They came eaten')

(Italian)

b. Maria era bevutissima / fumatissima.

Mary.FSG be.PST.3SG drink.PTCP.SUPERL.FSG Smoke.PTCP.SUPERL.FSG

'Mary was very drunk/stoned.'

The participles in question pass the standard tests for adjectivehood, as is shown by the gender and number agreement inflection (cf. 83a-b), as well as the modification with the superlative morphology in (83b) ${ }^{20}$ They also pass the tests for resultativity, in that they only allow repetitive readings, if modified with 'again' (cf. $84 \mathrm{a}, 85 \mathrm{a}$ ), and they are incompatible with expressions that negate prior events of eating, drinking, smoking, etc. (cf. 84b, 85b).
a. Vinniru
arrèri manciati.

come.PST.3PL again eat.PTCP.PL

(Sicilian)

'Once again, when they came, they had already eaten' (Lit. 'They came again eaten').' [repetitive not restituitive]

a. Vinniru manciati, (*ma unn'avianu manciatu).

come.PST.3PL eat.PTCP.PL but NEG have.PST.3PL eat.PTCP

'When they came, they had already eaten (*but they had not eaten).'
a. Maria era di nuovo bevuta.
(Italian)
Mary.FSG be.PST.3SG again drink.PTCP.FSG
'Mary was drunk again'. [repetitive, not restituitive]
b. Maria è bevuta, (*ma non ha bevuto).
Mary.FSG be.PST.3SG drink.PTCP.FSG but NEGhave.3SG drink.PTCP
'Mary is drunk, but she has not drunk.'

The same participles cannot be passive, as testified by their incompatibility with a by-phrase (cf. 86a). This is unsurprising because their argument corresponds to the thematically prominent argument of the homoradical verb: it is the eater/the drinker/the smoker and not the eaten/drunk/smoked thing. At the same time, these participial adjectives cannot be derived from a verbal base by decausativization because the homoradical verbs are not causative: note that the verbs in question must be embedded in a fare causative to be causativized (cf. 86b).

(86) a. Maria era di nuovo bevuta (*dal whisky).

(Italian)

Mary.FSG be.PST.3SG again drink.PTCP.FSG by.the whisky 'Mary was drunk again (by whisky)'.
b. Marco ha *fumato / fatto
fumare Lucia.
Mark have.3SG smoke.PTCP make.PTCP smoke.INF Lucy
'Mark made Lucy smoke.'

In fact, a number of members of this class of result state adjectives are related to monovalent activity verbs, which are intransitive and have no transitive or causative counterpart. Romanian umblat 'walked' is a case in point (cf. 87a), as is Sicilian

\footnotetext{
${ }^{20}$ In Sicilian the superlative is periphrastic (cf. 29b).
} 
sbagghiatu 'mistaken', which is homoradical with sbagghiari, lit. mistake (v.) (cf. $87 \mathrm{~b})^{21}$

(87) a. Om umblat.

(Romanian)

man walk.PTCP

'One who has walked.' (Lit. 'A walked man').

b. Sini sbagghiatu.

be.3SG wrong.PTCP.MSG

'You are mistaken.'

(Sicilian)

Since Romanian a umbla 'walk' and Sicilian sbagghiari 'make (a) mistake(s), be mistaken' are activities, they do not have a change of state component in their lexical semantic representation, i.e., a state predicate within the scope of the operator BECOME (cf. 18b). ${ }^{22}$ This is shown in the following lexical semantic representations, where do' is the generalized activity predicate marker (see $§ 7$ ).

(88) a. [do' (x, [walk' (x)])]

b. $\left[\right.$ do' $^{\prime}\left(\mathrm{x},\left[\right.\right.$ mistake' $\left.\left.\left.\left.^{\prime} \mathrm{x}\right)\right]\right)\right]$

Therefore, the derivation of the corresponding result-state adjectives cannot possibly involve deletion or reduction of a larger lexical semantic structure to a simple state (cf. 1a-b). Rather the meaning of this type of result state can only be built up monotonically, enriching a basic activity event template (cf. 88a-b) to yield a more complex event template.

As for the adjectival participles which are homophonous with verbal participles that can be transitive, we note that the verbal participles are not inflected forms of verbs meaning 'eat and become eaten (in the sense of 'full')', 'drink and become drunk', etc. Such verbs do not exist in the languages under discussion. Below we exemplify the transitivity alternation which characterises the relevant verbs.
a. Maria ha bevuto.
Mary have.3SG drink.PTCP
'Mary has drunk.'
b. Maria ha bevuto una birra.
Mary have.3sG drink.PTCP a beer
'Mary has drunk a beer.'

(Italian)

Importantly, the theme of the result state adjectives under discussion is solely a theme in a lexical semantic structure where it also takes an agent position. This is testified by the incompatibility of these result states with expressions that negate that the theme of the result state is also the agent of the corresponding activity.

\footnotetext{
21 For more extensive discussion of this class of result states, we refer to Bentley \& Ledgeway (2014, 2015) (see also Meyer Lübke 1899: 14-17, Tobler 1921: 40-41, Tuttle 1986, Haspelmath 1994).

${ }^{22}$ The reader should note that there are standard tests for the determination of the Aktionsart of verbs and predicates, mostly based on Dowty (1979) (see also Smith 1997, Van Valin \& LaPolla 1997: 91102).
} 
The evidence in (90) indicates that this class of result state adjectives describes a state that ensues from an activity with the same name (Italian bevuto describes an individual who is in the state of having drunk). The challenge is, thus, to start from the lexical semantic structure of an activity (cf. 91) and to derive a lexical semantic structure in which the argument of the activity is also the argument of a result state.

\section{$\left[\right.$ do' $^{\prime}\left(\mathrm{x},\left[\right.\right.$ pred' $\left.\left.\left.^{\prime}(\mathrm{x})\right]\right)\right]$}

There is actually independent evidence for this type of lexical semantic structure, which, in the framework for lexical decomposition adhered to here, is called active accomplishment (Van Valin \& LaPolla 1997, Van Valin 2005, 2017). The lexical semantic structure of active accomplishments combines an activity $\left(\right.$ do' $\left.^{\prime}(\mathrm{x}, \ldots)\right)$ with a simultaneous incremental process (PROC pred') and a consecutive change of state (INGR pred'). Other theories of lexical decomposition do not distinguish active accomplishments from other accomplishments (i.e., accomplishments with and without an activity) despite there being evidence for this distinction in many languages. Consider go. This verb describes an activity which is simultaneous to the process of covering an incremental path and leads to a change of location: the argument of the activity and the theme argument of the change of location are the same.

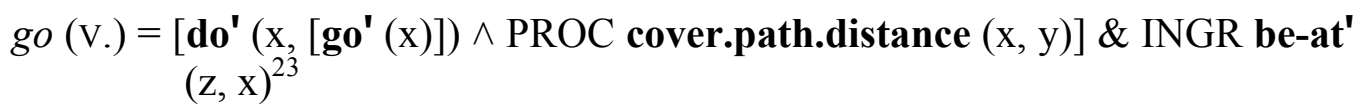

In (92) do' is the activity predicator, while PROC and INGR break down the operator BECOME into an incremental process and a discrete change of location. In the process PROC cover.path.distance $(x, y), y$ is the incremental path covered. In the change of location INGR be-at' $(z, x), z$ is the location, while $x$ is the theme. Crucially, the latter figures in the same lexical semantic representation as the argument of the activity do' $(\mathrm{x}, \ldots)$.

Interestingly, Italian andato 'gone' is attested in the informal registers as a result state meaning 'mentally gone' or 'not with it'. The formation of this result state on the basis of the lexical semantic structure in (92) is entirely unproblematic. In the stative adjective in (93), the final location $\mathrm{z}$ is the "mentally away" location, and the theme of the state be-at' $(\mathrm{z}, \mathrm{x})$ also figures as the agent of the activity do' (x, [go' $(\mathrm{x})])$.

$$
\begin{aligned}
\text { andato }(\mathrm{A} .)= & {\left[\text { be' } ^ { \prime } \left(\mathrm{x},\left[\left[\mathbf{d o}^{\prime}\left(\mathrm{x},\left[\text { go' }^{\prime}(\mathrm{x})\right]\right) \wedge \text { PROC cover.path.distance }(\mathrm{x}, \mathrm{y})\right] \&\right.\right.\right.} \\
& \text { INGR be-at' }(\mathrm{z}, \mathrm{x}) \& \text { be-at' }(\mathrm{z}, \mathrm{x})])]
\end{aligned}
$$

To return to Romanian umblat 'in the state of having walked' (cf. 87a), we argue that in the formation of this result state the activity root in (88a) is enriched to include an incremental walking process and a change of state leading to a result state whose argument is the same as that of the activity root.

\footnotetext{
${ }^{23} \wedge$ is the simultaneity symbol (Van Valin \& LaPolla 1997: 109). For the representation of active accomplishments involving movement (cf. 92) and consumption (cf. 95b), see Van Valin (2017).
} 
The lexical semantic structure in (94) describes a state which ensues from an activity and a process leading to a change of state.

Italian bevuto 'inebriated (as a result of drinking)' (similarly to Sicilian manciatu 'in the state of having eaten', Italian fumato 'stoned (as a result of smoking hash)', etc.) is homoradical with an activity or bivalent active accomplishment verb (cf. 89a and, respectively, 89b). The respective lexical semantic structures are illustrated here.

(95) a. do' (x, [drink' (x (y))]) 'drink (intr. v.)' [activity, cf. 89a]

b. [do' $\left(x,\left[\right.\right.$ drink' $\left.\left.^{\prime}(x, y)\right]\right) \wedge$ PROC consume' $\left.(x, y)\right] \&$ INGR consumed' $(y)$ 'drink (tr. v.)' [active accomplishment, cf. 89b]

The result state bevuto 'inebriated, drunk' cannot be formed on the basis of the bivalent active accomplishment in $(95 \mathrm{~b})$ because the theme of this active accomplishment (y) is not the theme of the result state (it is the drunk thing, not the drinker). Accordingly, we have to assume that the starting point of the relevant morpho-semantic operation is, again, an activity with an agent actant argument (cf. 95a). The derivation of the result state involves enrichment to include an incremental process and a change of state leading to a result state whose argument is the same as that of the activity.
bevuto (A.) $=\left[\right.$ be' $^{\prime}\left(\mathrm{x},\left[\mathbf{d o}^{\prime}\left(\mathrm{x},\left[\mathbf{d r i n k} \mathbf{k}^{\prime}\right.\right.\right.\right.$ in.the.state.of.having.drunk'
$(\mathrm{x})]) \wedge$ PROC drink' (x)] \& INGR $(\mathrm{x})])]$
(x) \& in.the.state.of.having.drunk'

The most puzzling class of result state adjectives is thus unproblematic in terms of its thematic structure, in that its argument is the theme of a state that results from a change of state. Importantly, for our purposes, this class provides patent evidence in support of monotonicity in word formation, since it is impossible to derive the adjectives in question with a deletion analysis.

As for the morphological operation that underlies the process discussed above, again, these adjectival participles could be formed by conversion, i.e., from the homophonous participles of activity verbs. In this case, the conversion analysis is challenged by the observation that, in the substandard or emergent registers of Italian, one finds adjectival participles with meanings that are comparable to those of the participles under discussion here, but which have no verbal correlate. An example of this is provided here.
Siamo arrivati
già bigliettati.
(Italian)
be.1PL arrive.PTCP.MPL already ticket.PTCP.MPL
'When we arrived, we already had a ticket.'
(Tullio Telmon, p.c., December 2014)

The adjective bigliettato, lit. 'ticketed', cannot be formed from a homophonous verbal participle, since there is no verb bigliettare in Italian. Similarly, francobollato, which is used synonymously to affrancato 'stamped', figures in emergent Italian, but does 
not yet appear in all dictionaries, and could be formed on the basis of the noun francobollo 'stamp'.

We also refer to Bentley \& Ledgeway (2014) for a Neapolitan rhizotonicarrhizotonic pair, vippeto vevùta 'drunk', where the rhizotonic member can have the same meaning as Italian bevuto 'inebriated (as a result of drinking)', i.e., it can be a result state participle which is patently not formed by conversion from the verbal participle.

Therefore, we extend our proposal to this class. Clearly, the participial allomorph attaches here to a thematic base, as testified by the thematic vowel found on the adjectival result states. However, the thematic base need not be verbal, as is patently the case with bigliettato 'one who has a ticket'. In fact, in light of the thematic discrepancy between these result states and the homophonous verbal participles, we suggest that the operation starts from an activity root (intended as a morphological object with a semantic correlate in a lexical semantic structure), which is enriched to form a thematic base to which $-T$ - is attached.

To conclude, taking a broader look at result state participles, we have challenged the non-monotonic analyses even further. We pointed out that there are classes of result state participles which do not describe the result of externally-caused events and are not homophonous with the participles of causative verbs. We claimed that these cannot be formed by decausativization. In addition, we noted that there are result state participles whose theme corresponds to the agent of homophonous participles of activity verbs. We argued that the formation of this latter class cannot involve deletion, but rather they must be formed incrementally starting from an activity root. In the last analysis, while the investigation of Italo-Romance result state adjectives fully supports the differentiation between passive (agentive) and nonpassive (non-agentive) result states (Dubinsky \& Simango 1996, Meltzer-Asscher 2011 , etc.), decausativization cannot be a defining operation in the formation of nonpassive result states. In more general terms, the result state adjectives of ItaloRomance fully support a monotonic account that involves semantic enrichment, rather than deletion.

\section{CONCLUSION}

The principal aim of this article was to put to test Koontz-Garboden's (2005, 2007, 2009, 2010, 2012) Monotonicity Hypothesis, considering evidence from ItaloRomance rhizotonic athematic participles describing result states (e.g., Italian rotto 'broken', Sicilian frittu 'fried', Milanese succ' 'dry/dried'). Cognate rhizotonic participles in other Romance languages have been claimed to pose a challenge to the hypothesis, as have the result states of other languages, which have received nonmonotonic, decausative, analyses.

Capitalizing on non-homophonous adjectival pairs, where only one member is rhizotonic and athematic, while the other is arrhizotonic and thematic (e.g., Italian asciutto/asciugato 'dry/dried', Sicilian frittu/frijutu 'fried', Milanese succ'/sugaa 'dry/dried'), we found that Italo-Romance supports the distinction between passive (or agentive) and non-passive (or non-agentive) result state adjectives proposed in previous scholarship (Dubinsky \& Simango 1996, Anagnostopoulou 2003, Embick 2004, Meltzer-Asscher 2011, Anagnostopoulou \& Samioti 2013, Pescia 2015). We claimed that the non-passive adjectives are formed by attaching a participial allomorph to a root, while, following the traditional analysis (Scalise 1995, Thornton 
2004, Schwarze 2017, among others), we took the passive adjectives to be formed by conversion from verbal participles.

Applying the relevant compatibility and contradiction tests, we ascertained that the rhizotonic adjectives have event entailments. In particular, they describe changes of state which can potentially be externally caused (break, dry, fry, wear out, stretch, light up, etc.). While these adjectives lack a cause in their lexical semantic structure, we found no evidence of decausativization (deletion of a causer), in contrast with existing claims on the semantics of comparable classes of result states in other languages. We argued that the said claims are based on the incorrect interpretation of the results of a compatibility test.

Broadening the domain of our investigation, we considered other classes of nonpassive result states, which are unambiguously non-causative and cannot be formed by decausativization. One of these classes is particularly significant, in that the thematic difference between the adjectival participles in question and the homophonous verbal participles seriously challenges a non-monotonic analysis, suggesting instead that the meaning of the result states is formed by enriching a basic event template.

We thus developed a monotonic proposal on the derivational process that forms non-passive result-state adjectives. According to this proposal, a participial allomorph attaches to an eventive root or thematic base to yield a stative adjective. Direct attachment to a root characterizes a fairly homogeneous lexical semantic class, describing changes of state that can potentially be externally caused. Since we found no evidence of decausativization, or of the loss of any decompositional operator, in any of the classes taken into consideration, we proposed that these adjectives are unproblematic for the Monotonicity Hypothesis.

We conclude that, although the Monotonicity Hypothesis ought to be tested further, with evidence from more languages and other word formation processes, our findings strongly support the monotonicity principle.

\section{REFERENCES}

Anagnostopoulou, Elena, 2003. 'Participles and voice', in Artemis Alexiadou, Monika Rathert \& Arnim von Stechow (eds.), Perfect Explorations, Berlin: Mouton de Gruyter, 1-36.

Anagnostopoulou, Elena \& SAmioti, Yota, 2013. 'Allosemy, idioms, and their domains: evidence from adjectival participles', in Raffaella Folli, Christina Sevdali \& Robert Truswell (eds.), Syntax and its limits, Oxford: Oxford University Press, 218-250.

Ascoli, Graziadio Isaia, 1876. 'Ricordi bibliografici', Archivio Glottologico Italiano 2, 395-458.

Beavers, John, Everdell, Michael, Jerro, Kyle, Kauhanen, Henri, KoontzGarboden, Andrew, LeBovidge, Elise \& Nichols, Stephen, 2017. 'Two Types of States: A Cross-linguistic Study of Change-of-State Verb Roots', Paper given at the Annual Meeting of the Linguistic Society of America, 6 January 2017, Austin, TX.

BeNTLEy, Delia, 2006. Spit intransitivity in Italian, Berlin: Mouton.

Bentley, Delia, 2012. 'Una explicación unificada de las construcciones con si en italiano', in Ricardo Mairal, Lilián Guerrero and C. González (eds.), El funcionalismo en la teoría lingüistica. La Gramática del Papel y la Referencia. Avances y aplicaciones, Madrid: Ediciones Akal, 152-170. 
Bentley, Delia, 2016. 'Spit intransitivity', in Adam Ledgeway \& Martin Maiden (eds.), Oxford Guide to the Romance Languages, Oxford: Oxford University Press, 821-832.

Bentley, Delia \& Ledgeway, Adam, 2014. 'Manciati siti? Les constructions moyennes avec les participes résultatifs statifs dans l'italien et les variétés italoromanes méridionales', Langages 194, 63-80.

Bentley, Delia \& Ledgeway, Adam, 2015. 'Autour de la question des participes résultatifs-statifs dans les variétés romanes', in Ignazio Mirto (ed.), Le relazioni irresistibili, Pisa: Edizioni ETS, 61-91.

Bosque, Ignacio, 2014. 'On Resultative Past Participles in Spanish', Catalan Journal of Linguistics 13, 41-77.

Cennamo, Michela, 1993. The Reanalysis of Reflexives: A Diachronic Perspective, Napoli: Liguori.

Cennamo, Michela, 1999. 'Late Latin Pleonastic Reflexives and the Unaccusative Hypothesis', Transactions of the Philological Society 97, 103-150.

Cennamo, Michela, 2012. 'Aspectual constraints on the (anti)causative alternation in Old Italian', Transactions of the Philological Society 110, 394-421.

Cennamo, Michela, 2017. 'The reanalysis of reflexives as transitivity modulators in Romance', Paper delivered at the $50^{\text {th }}$ Annual Meeting of the Societas Linguistica Europaea, University of Zurich, 10-13 September 2017.

CENNAmo, Michela, Éythorssórsson, ThÓRhallur \& BARĐDAl, JOHANNA, 2015. 'Semantic and (morpho)syntactic constraints on anticausativization: evidence from Latin and Old Norse-Icelandic', Linguistics 53, 677-729.

Cortelazzo, Manlio \& Zolli, PaOlo, 1988. Dizionario etimologico della lingua italiana, Bologna: Zanichelli.

CREISSELS, DENIS, 2003. 'L'emploi résultatif de être + participe passé en français', Cahiers Chronos 6, 133-142.

DiXON, RoBert M. W., 1982. Where Have All the Adjectives Gone?: and Other Essays in Semantics and Syntax, The Hague: Mouton.

Dowty, DAVID R., 1979. Word meaning and Montague Grammar, Dordrecht: Reidel.

Dubinsky, Stanley \& Simango, Silvester Ron, 1996. 'Passive and stative in Chicheŵa: Evidence for modular distinctions in grammar', Language 72, 749-781.

EMBICK, DAVID, 2004. 'On the Structure of Resultative Participles in English', Linguistic Inquiry 35, 355-392.

HASPELMATH, MARTin, 1994. 'Passive participles across languages', in Barbara A. Fox \& Paul J. Hopper (eds.), Voice: Form and Function, Amsterdam/Philadelphia: John Benjamins, 151-177.

KIPARSKY, PAUL, 1982. 'Word formation and the lexicon', in Frances Ingemann (ed.), Proceedings of the 1982 Mid-America Linguistics Conference, 3-29.

KoOnTZ-Garboden, ANDrew, 2005. 'On the Typology of State/Change of State Alternations', Yearbook of Morphology. 83-117.

KoONTZ-GARBODEN, ANDREw, 2007. States, Changes of State, and the Monotonicity Hypothesis, Stanford University Ph.D. dissertation.

KoONTZ-GARBODEN, ANDREW, 2009. 'Anticausativization', Natural Language and Linguistic Theory 27, 77-138.

Koontz-Garboden, Andrew, 2010. 'The Lexical Semantics of Derived Statives', Linguistics and Philosophy 33, 285-324.

KoOntz-Garboden, Andrew, 2012. 'The Monotonicity Hypothesis', in Louise McNally \& Violeta Demonte (eds.), Telicity, Change, and State. A CrossCategorial View of Event Structure, Oxford: Oxford University Press, 139-161. 
Kratzer, AngeliKa, 1994. The event argument and the semantics of voice. Ms., University of Massachusetts, Amherst.

KRATZER, ANGELIKA, 1996. 'Severing the external argument from its verb', in Johan Rooryck \& Laurie Zaring (eds.), Phrase Structure and the Lexicon, Dordrecht: Kluwer, 109-138.

Kratzer, Angelika, 2000. 'Building Statives', Berkeley Linguistics Society 26, 385 399.

Labelle, Marie, 1992. 'Change of State and Valency', Journal of Linguistics 28, 375-414.

LaUrent, Richard, 1999, Past Participles from Latin to Romance, Berkeley and Los Angeles: University of California Press.

Ledgeway, Adam, 2000. A Comparative Syntax of the Dialects of Southern Italy: A Minimalist Approach. Oxford: Blackwell.

Ledgeway, AdAM, 2016. 'Italian, Tuscan, and Corsican', in Adam Ledgeway and Martin Maiden (eds.), The Oxford Guide to the Romance Languages, Oxford: Oxford University Press, 206-227.

Levin, Beth, 1993. English Verb Classes and Alternations: A Preliminary Investigation, Chicago: University of Chicago Press.

LEVIN, BeTH \& RAPPAPORT Hovav, MALKA, 1986. 'The formation of adjectival passives', Linguistic Inquiry 17, 623-661.

Levin, Beth \& Rappaport Hovav, Malka, 1995. Unaccusativity. At the SyntaxLexical Semantics Interface, Cambridge, Mass.: The MIT Press.

LoporCARO, Michele, 1998. Sintassi comparata dell'accordo participiale romanzo, Torino: Rosenberg \& Sellier.

Loporcaro, Michele, Pescia Lorenza \& Ramos M. A., 2004. 'Costrutti dipendenti participiali e participi doppi in portoghese', Revue de linguistique romane 68, 15-46.

MAIDEN, MARTIN, 1995. A Linguistic History of Italian, London: Longman.

MAiden, MARTin, 2016. 'Morphomes', in Adam Ledgeway \& Martin Maiden (eds.), Oxford Guide to the Romance Languages, Oxford: Oxford University Press, 708721.

MAIDEN, MARTIN \& PARRY, MAIR M. (eds.), 1997. The Dialects of Italy. London: Routledge.

Maienborn, Claudia, 2009. 'Building Event-Based Ad Hoc Properties: On the Interpretation of Adjectival Passives', in Arndt Riester \& Torgrim Solstad (eds.), Proceedings of Sinn und Bedeutung 13, Stuttgart: Universitätsbibliothek der Universität Stuttgart, 35-49.

MeYer-LÜBKe, Wilhelm, 1899. Grammatik der Romanischen Sprachen. Dritter Band: Syntax, Leipzig: Reisland.

Meltzer-Asscher, Aya, 2011. 'Adjectival passives in Hebrew: evidence for parallelism between the adjectival and verbal systems', Natural Language and Linguistic Theory 29, 815-855.

Pescia, Lorenza, 2011. 'La doppia serie di participi passati nel dialetto galloitalico di Picerno', in Simone Casini, Carla Bruno, Francesca Gallina \& Raymond Siebetcheu (eds.), Plurilinguismo. Sintassi. Atti del XLVI congresso internazionale di studi della società di linguistica italiana (SLI) - Siena, 27-29 settembre 2012. Società di linguistica italiana, 59, Roma: Bulzoni, 525-536.

Pescia, Lorenza, 2015. Sintassi e semantica delle forme participiali doppie e alternanti, con particolare riguardo all'italo-romanzo. Universität Zürich, Philosophische Fakultät, PhD Dissertation. 
Porroche Ballesteros, Margarita, 1990. Aspectos de la atribución en español: las construcciones con un atributo adjetivo que se refiere al sujeto, Zaragoza: Libros Pórtico.

RAPPAPORT Hovav, Malka \& Levin, Beth. 1998. 'Building verb meanings', in Miriam Butt and Wilhelm Geuder (eds.), The projection of arguments: Lexical and compositional factors, Stanford, CA: CSLI Publications, 97-134.

ROHLFS, GERHARD, 1968. Grammatica storica della lingua italiana e dei suoi dialetti. Morfologia, Torino: Einaudi.

ROTHEMBERG, MirA, 1974. Les verbes à la fois transitifs et intransitifs en français contemporain, Paris: Mouton.

SCALise, Sergio, 1995. 'La formazione delle parole', in Lorenzo Renzi, Giampaolo Salvi \& Anna Cardinaletti (eds.), Grande grammatica italiana di consultazione. Vol. III. Tipi di frase, deissi, formazione delle parole, Bologna: il Mulino, 471-514.

SCHWARZE, ChristoPH, 2017. 'A proposito delle restrizioni sulla conversione di participi in aggettivi', in Roberta D'Alessandro, Gabriele Iannàccaro, Diana Passino and Anna M. Thornton (eds.), Di tutti i colori. Studi linguistici per Maria Grossmann, Utrecht University Repository, 301-317. Available at https://www.ris.uu.nl/ws/files/34667598/Di_tutti_i_colori.pdf.

Smith, CARlotta, 1997. The Parameter of Aspect, Dordrecht: Reidel, 2nd ed.

STUMP, GRegORY, 1998. 'Inflection', in Andrew Spencer \& Arnold Zwicky (eds.), Handbook of Morphology, Oxford: Blackwell, 13-43.

Telve, Stefano, 2017, Anticausatività e passività. Il costrutto "rimanere" + participio passato. Uno studio di sintassi dell'italiano in diacronia, Heidelgerg: Winter.

Thornton, Anna, 2004. 'Conversione in aggettivi', in Maria Grossmann \& Franz Rainer (eds.), La formazione delle parole in italiano, Tübingen: Niemeyer, 526533.

Tobler, Adolph, 1921. Participia perfecti aktiven Sinnes, in Adolph Tobler (ed.), Vermischte Beiträge zur Französischen Grammatik, Leipzig: S. Hirzel, 151-165.

TUTTLE, EDWARD, 1986. 'The spread of ESSE as universal auxiliary in central ItaloRomance', Medioevo romanzo 11, 229-287.

VAN VAlin, ROBERT JR., 2005. Exploring the Syntax-Semantics Interface, Cambridge: Cambridge University Press.

VAN VALIN, RoBert JR., 2017. 'Some issues regarding (active) accomplishments', in Rohlf Kailuweit, Lisann Künden \& Eva Staudinger (eds.), Applying and Expanding Role and Reference Grammar.

Van VAlin, Robert JR. \& LaPolla, Randy, 1997. Syntax. Structure, meaning and function, Cambridge: Cambridge University Press.

VON STECHOW, ARNIM. 1996. The different readings of Germ. "wieder" (again). A Structural account. Available at http://www.sfs.uni-tuebingen.de/ astechow/ Aufsaetze/index.html.

Wasow, Thomas, 1977. 'Transformations and the Lexicon', in Peter W. Culicover, Thomas Wasow \& Adrian Akmajian (eds.), Formal Syntax, New York: Academic Press, 327-360. 